\title{
DNA barcode data accurately assign higher spider taxa
}

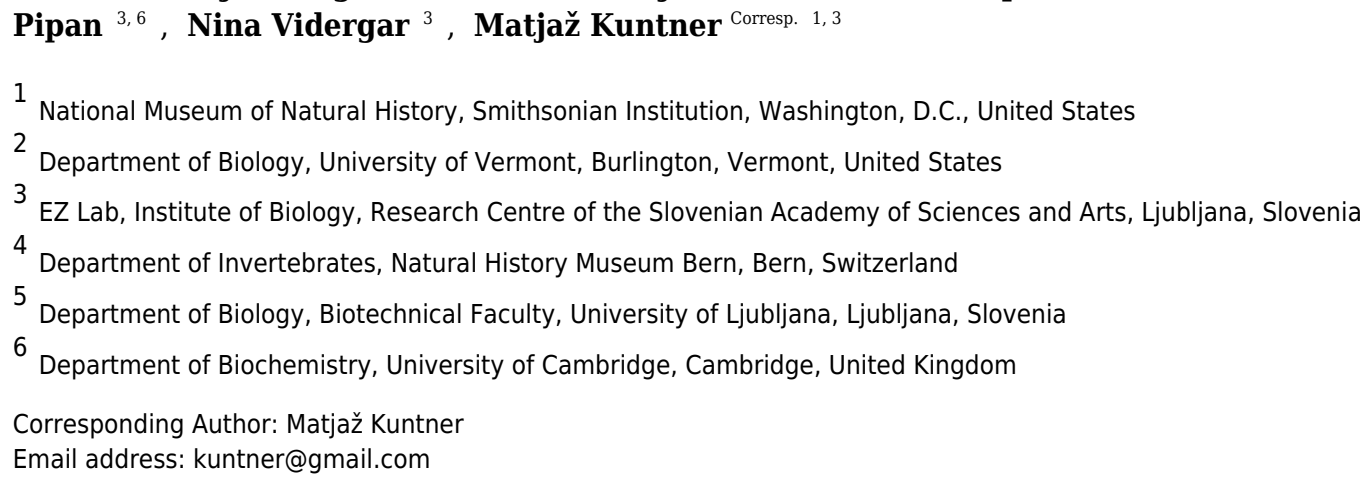

The use of unique DNA sequences as a method for taxonomic identification is no longer fundamentally controversial, even though debate continues on the best markers, methods, and technology to use. Although both existing databanks such as GenBank and BOLD, as well as reference taxonomies, are imperfect, in best case scenarios "barcodes" (whether single or multiple, organelle or nuclear, loci) clearly are an increasingly fast and inexpensive method of identification, especially as compared to manual identification of unknowns by increasingly rare expert taxonomists. Because most species on Earth are undescribed, a complete reference database at the species level is impractical in the near term. The question therefore arises whether unidentified species can, using DNA barcodes, be accurately assigned to more inclusive groups such as genera and families-taxonomic ranks of putatively monophyletic groups for which the global inventory is more complete and stable. We used a carefully chosen test library of CO1 sequences from 49 families, 313 genera, and 816 species of spiders to assess the accuracy of genus and family-level assignment. We used BLAST queries of each sequence against the entire library and got the top ten hits. The percent sequence identity was reported from these hits (PIdent, range 75-100\%). Accurate assignment of higher taxa (PIdent above which errors totaled less than $5 \%$ ) occurred for genera at Pldent values $>95$ and families at PIdent values $\geq 91$, suggesting these as heuristic thresholds for accurate generic and familial identifications in spiders. Accuracy of identification increases with numbers of species/genus and genera/family in the library; above five genera per family and fifteen species per genus all higher taxon assignments were correct. We propose that using percent sequence identity between conventional barcode sequences may be a feasible and reasonably accurate method to identify animals to family/genus. However, the quality of the underlying 
database impacts accuracy of results; many outliers in our dataset could be attributed to taxonomic and/or sequencing errors in BOLD and GenBank. It seems that an accurate and complete reference library of families and genera of life could provide accurate higher level taxonomic identifications cheaply and accessibly, within years rather than decades. 


\section{DNA barcode data accurately assign higher spider taxa}

2

3

4

Jonathan A. Coddington *1, Ingi Agnarsson ${ }^{1,5}$, Ren-Chung Cheng ${ }^{2}$, Klemen Čandek ${ }^{2}$, Amy Driskell ${ }^{1}$, Holger Frick ${ }^{3}$, Matjaž Gregorič ${ }^{2}$, Rok Kostanjšek ${ }^{4}$, Christian Kropf ${ }^{3}$, Matthew Kweskin ${ }^{1}$, Tjaša Lokovšek ${ }^{2}$, Miha Pipan ${ }^{2,6}$, Nina Vidergar ${ }^{2}$, Matjaž Kuntner $* 1,2$

${ }^{1}$ National Museum of Natural History, Smithsonian Institution, Washington, DC, USA

${ }^{2}$ EZ Lab, Institute of Biology at Research Centre of the Slovenian Academy of Sciences and Arts, Ljubljana, Slovenia

${ }^{3}$ Department of Invertebrates, Natural History Museum Bern, Switzerland

${ }^{4}$ Department of Biology, University of Ljubljana, Slovenia

${ }^{5}$ Department of Biology, University of Vermont, Burlington, VT, USA

${ }^{6}$ Currently at: Department of Biochemistry, University of Cambridge, Cambridge, CB2 1GA, United Kingdom

\section{*Authors for correspondence}

Jonathan A. Coddington, Department of Entomology, National Museum of Natural History, Smithsonian Institution, Washington, D.C. 20013-7012, USA, coddington@si.edu and

Matjaž Kuntner, Research Centre, Slovenian Academy of Sciences and Arts, Novi trg 2, P.O. Box 306, SI-1001, Ljubljana, Slovenia, kuntner@gmail.com

Keywords: taxonomic impediment, genus, family, genome, Global Genome Initiative, Smithsonian. 
26 Abstract

27 The use of unique DNA sequences as a method for taxonomic identification is no longer 28 fundamentally controversial, even though debate continues on the best markers, methods, and 29 technology to use. Although both existing databanks such as GenBank and BOLD, as well as 30 reference taxonomies, are imperfect, in best case scenarios "barcodes" (whether single or multiple, organelle or nuclear, loci) clearly are an increasingly fast and inexpensive method of identification, especially as compared to manual identification of unknowns by increasingly rare expert taxonomists. Because most species on Earth are undescribed, a complete reference database at the species level is impractical in the near term. The question therefore arises whether unidentified species can, using DNA barcodes, be accurately assigned to more inclusive groups such as genera and families - taxonomic ranks of putatively monophyletic groups for which the global inventory is more complete and stable. We used a carefully chosen test library of CO1 sequences from 49 families, 313 genera, and 816 species of spiders to assess the accuracy of genus and family-level assignment. We used BLAST queries of each sequence against the entire library and got the top ten hits. The percent sequence identity was reported from these hits (PIdent, range 75-100\%). Accurate assignment of higher taxa (PIdent above which errors totaled less than 5\%) occurred for genera at PIdent values $>95$ and families at PIdent values $\geq 91$, suggesting these as heuristic thresholds for accurate generic and familial identifications in spiders. Accuracy of identification increases with numbers of species/genus and genera/family in the library; above five genera per family and fifteen species per genus all higher taxon assignments were correct. We propose that using percent sequence identity between conventional barcode sequences may be a feasible and reasonably accurate method to identify animals to family/genus. However, the quality of the underlying database impacts accuracy of results; many outliers in our dataset could be attributed to taxonomic and/or sequencing errors in BOLD and GenBank. It seems that an accurate and complete reference library of families and genera of life could provide accurate higher level taxonomic identifications cheaply and accessibly, within years rather than decades. 


\section{Introduction}

Accurate identification of biological specimens has always limited the application of biological data to important societal problems. Obstacles are well-known and difficult: the vast majority of species are undescribed scientifically (Erwin, 1982; May, 1992; Mora et al., 2011); some unknown but large fraction of higher taxa are not monophyletic (Goloboff et al., 2009; Pyron \& Wiens, 2011); many species can only be identified if certain life stages are available, e.g. adults (Coddington \& Levi, 1991), classical data sources such as morphology imperfectly track species identity; the discipline of taxonomy continues to dwindle; the classical process of taxonomic identification is mostly manual and cannot scale to provide the amounts of data required for realtime decisions such as environmental monitoring, invasive species, climate change, etc.

DNA sequence data potentially can eliminate most of these obstacles. DNA barcoding uses a fragment of the mitochondrial gene cytochrome $c$ oxidase subunit I (CO1) as a unique species diagnosis/identification tool in the animal kingdom (Hebert et al., 2003), with analogous single to several locus protocols applied for vascular plants, ferns, mosses, algae and fungi (Saunders, 2005; Kress \& Erickson, 2007; Nitta, 2008; Chase \& Fay, 2009; Liu et al., 2010;), protists (Scicluna, Tawari \& Clark, 2006), and prokaryotes (Barraclough et al., 2009). Due to relative ease and inexpensive sequencing, DNA barcoding is a popular tool in species identification and taxonomic applications (e.g. Doña et al., 2015; Xu et al., 2015; see also Collins \& Cruickshank, 2013), and the method is no longer fundamentally controversial at the species level (Pentinsaari, Hebert \& Mutanen, 2014; Lopardo \& Uhl, 2014; Čandek \& Kuntner, 2015; Anslan \& Tedersoo, 2015; Wang et al., 2015).

While most species remain undescribed, the situation is not so dire for larger monophyletic groups such as clades accorded the Linnaean ranks of genus or family. In assessing the state of knowledge about biodiversity, it is important to distinguish between the first scientific discovery of an exemplar of a lineage, and phylogenetic understanding of that lineage. Phylogenetic understanding — both tree topology and consequent taxonomic changes, are research programs with no clear end in sight. Linnaean rank is partially arbitrary, and one expects that the number of higher taxa will probably increase over time as understanding improves. Discovery, however, can have an objective definition: the year of the earliest formal taxonomic description of a member of the lineage or taxonomic group in which it is currently included. By this definition the earliest possible discovery of an animal lineage is 1758 (Linnaeus, 1758), or in the case of spiders, 1757 (Clerck, 1757).

More illuminating are the latest discoveries of lineages with the rank of family within larger clades, because the data tell us something about progress towards broad scale knowledge of biodiversity. The species representing the most recent discovery of a family of birds, for example, is the Broad-billed Sapayoa, Sapayoa aenigma Hunt, 1903 (Sapayoaidae). The species representing the most recently discovered mammal family is Kitti's hog-nosed bat, Craseonycteris thonglongyai Hill, 1974 (Craseonycteridae). For flowering plants, it is Gomortega keule (Molina) Baill, 1972 (Gomertegaceae). For bees, it is Stenotritus elegans Smith, 1853 (Stenotritidae). For spiders, a megadiverse and poorly known group, it is Trogloraptor marchingtoni Griswold, Audisio \& Ledford, 2012 (Trogloraptoridae), but the second most recent discovery of an unambiguously new spider family was in 1955 , Gradungulidae (Forster, 1955). Figure 1 illustrates the tempo of first discovery of families for these five well-known clades. At the family level, these curves are essentially asymptotic, 
99 implying that science is close to completing the inventory of clades ranked as families for these

100 large lineages. On the other hand, for Bacteria and Archaea (Figure 1), as one would expect, the

101 curve is not asymptotic at all but sharply increasing; prokaryote discovery and understanding is

102 obviously just beginning.

103 In fact, although many new eukaryote families are named every year, the vast majority of these

104 new names result from advances in phylogenetic understanding, not biological discovery of

105 major new forms of life. The last ten years of Zoological Record suggests that roughly 5-10 truly

106 new families are discovered per year.

107 In the context of the above question - approximate taxonomic assignment of organisms using

108 DNA sequences - these data suggest that our knowledge of major clades of life is approaching

109 completion. The Global Genome Initiative (GGI; http:// http://ggi.si.edu/) of the Smithsonian

110 Institution via the GGI Knowledge Portal (http://ggi.eol.org/) has tabulated a complete list of

111 families of life, which total 9,650 - on the whole a surprisingly small number. 10,000 barcodes,

112 more or less, seems like a feasible goal. If we were able to assemble a complete database of

113 DNA sequences at the family level, would it suffice to identify any eukaryote on Earth to the

114 family level?

115 While the literature on species identification success of DNA barcodes comprises thousands of

116 studies, only a few have tested their effectiveness at the level of higher taxonomic units. In the

117 seminal paper on DNA barcodes Hebert et al. (2003) established that animal CO1 sequences can

118 roughly assign taxa to phyla ( $96 \%$ success) or orders (100\% success). However, their test was

119 based on a neighbor joining tree-building approach, and it remained unknown if sequence data

120 itself, i.e. percent identity among taxa, can be used in this way. Similarly, Nagy et al. (2012)

121 showed that DNA barcoding in reptiles usually correctly assigned barcodes to species, genus and

122

123

124 family. Their approach was phylogenetic: they tested whether including a sequence in tree building rendered the higher group non-monophyletic, which would imply failure. Finally, Wilson et al. (2011) provided a similar tree based test in sphingid moths, and established

125

126 reliabilities of correct generic and subfamily taxonomic assignments between 74 and $90 \%$ using a liberal, and only 66-84\% using a strict, tree-based criterion. These authors argued that treebased methods perform better than sequence comparison methods, but that reliability, of course, depends on the library completeness.

Our project not only contributes original DNA barcode data for Central European spiders, but also works in synergy with the GGI towards a permanent preservation of genomic biodiversity: the formation of a collection of deeply frozen spider tissues and their DNA. We provide: 1) cryopreserved tissues of reliably identified species of Central European spiders, and their vouchers photographed and deposited in public museums; 2) permanently frozen genomic DNA of these species; 3) publicly accessible DNA barcodes for these species (genetic sequence of cytochrome oxidase I - CO1) as public identification tool (Hebert et al., 2003) to facilitate organism identification, taxonomy, ecology and conservation.

137 In addition, this project addresses to what extent higher level taxonomic units can be reliably

138 identified using barcodes of unknown spiders, and specifically asks what percent sequence

139 identity in BLAST results is necessary to correctly identify unknown taxa to the Linnaean genus

140 and/or family. Other methods for classification of higher-level taxonomies such as RDP (Wang

141 et al., 2007), UTAX (Edgar, 2010) and MEGAN (Huson et al., 2007) have primarily been 
142 developed for studies of microorganisms, using genetic markers for these groups, but less is

143 known about using the CO1 barcoding gene in metazoans. We examine empirical data from

144 Araneae barcode data to ask what is the percent sequence identity value above which 5\% or less

145 of higher level (genus/family) taxonomic identifications are incorrect and the extent to which

146 frequency of correct identifications correlated with the number of taxa in this dataset, as would

147 be expected given the dependence of BLAST on the reference database.

\section{Materials \& Methods}

150

151

Specimen processing and imaging

152

153

154

155

We used automated and manual sampling methods for collecting spiders in the field in numerous localities in Slovenia and Switzerland. Faunistic and sampling details are published elsewhere (Čandek et al., 2013; see also 2015 corrigendum). Collected spiders were fixed in absolute ethanol immediately after being caught and the ethanol was replaced on the following day. Spiders were frozen at $-80^{\circ} \mathrm{C}$, same day, or as soon as possible. In the laboratory they were identified, labeled, photographed and processed for DNA extraction and sequencing (Čandek et al., 2013; see also 2015 corrigendum). Voucher specimens (voucher codes starting with 0078) are deposited at National Museum of Natural History, Smithsonian Institution (Washington D.C., USA), with duplicates (voucher codes starting with ARA) at Naturhistorisches Museum der Burgergemeinde Bern (Switzerland) and EZ LAB, ZRC SAZU (Ljubljana, Slovenia).

162

163

164

Voucher images are published along with their barcodes (see Table 1) at http://ezlab.zrcsazu.si/dna. All original sequences generated by this project have been submitted to BOLD systems, and those that BOLD accepted were also submitted to GenBank (Table 1).

\section{Tissues}

After specimen identification and processing, up to four legs (or in the case of very small individuals the whole prosoma) of a spider were removed and stored in fresh absolute ethanol in cryovials. Part of the tissue was used for DNA isolation while the other part remains permanently frozen at $-80{ }^{\circ} \mathrm{C}$ at GGI facilities. The maintenance and use of these materials abides by the international legal standards and conventions of the biological genetic heritage (The Access and Benefit Sharing agreement as part of the 2010 Nagoya protocol).

\section{Molecular procedures}

176 At Laboratories of Analytical Biology (National Museum of Natural History, Smithsonian

177 Institution, hereafter LAB), specimens were extracted using the AutoGenPrep phenol-chloroform automated extractor (AutoGen). Samples were digested overnight in buffer containing proteinase-k before extraction. At EZ Lab, specimens were extracted using the Mag MAX ${ }^{\mathrm{TM}}$

180 Express magnetic particle processor Type 700 with DNA Multisample kit (Applied Biosystems, 181 Foster City, CA) following the manufacturer's protocols.

182 At EZ Lab PCR was carried out using mainly primers LCO1490 and HCO2198 (Folmer et al., 1994). Standard reaction volume was $35 \mu \mathrm{L}$ containing $2.3 \mathrm{mM} \mathrm{MgCl}{ }_{2}$ (Promega), $0.15 \mathrm{mM}$ each dNTP (Biotools), $0.4 \mu \mathrm{M}$ of each primer, $0.2 \mu \mathrm{L} 10 \mathrm{mg} / \mathrm{mL}$ BSA (Promega), $0.2 \mu \mathrm{L}$ GoTaqFlexi polymerase (Promega) and $2 \mu \mathrm{L}$ DNA. PCR cycling conditions were as follows: an initial denaturation step of $2 \mathrm{~min}$ at $94^{\circ} \mathrm{C}$ followed by 35 cycles of $40 \mathrm{sec}$ at $94^{\circ} \mathrm{C}, 1 \mathrm{~min}$ at $48^{\circ}$ - 
$18852^{\circ} \mathrm{C}, 1 \mathrm{~min}$ at $72^{\circ} \mathrm{C}$, with final extension at $72^{\circ} \mathrm{C}$ for $3 \mathrm{~min}$. Additional primers were used for 189 PCR for a few problematic specimens: dgLCO1490 and dgHCO2198 (Meyer \& Paulay, 2005) 190 and the reverse primer Chelicerate-R2 (Barrett \& Hebert, 2005). Cycling parameters for difficult 191 specimens were: 20 cycles of usual cycling protocol (above) followed by 15 cycles of $1.5 \mathrm{~min}$ at

$19294^{\circ} \mathrm{C}, 1.5 \mathrm{~min}$ at $52^{\circ} \mathrm{C}$ and $2 \mathrm{~min}$ at $72^{\circ} \mathrm{Cm}$ version 5.6.6 (Kearse et al., 2012). EZ Lab PCR

193 products were sent to be Sanger sequenced at Macrogen Inc. (Amsterdam, Netherlands), and the 194 sequences were aligned, checked for sequencing errors and trimmed to match the barcode region in Geneious Pro version 5.6.6 (Kearse et al., 2012).

At LAB, PCR was carried out using the primer pair LCO1490 (Folmer et al., 1994) and Chelicerate-R2 (Barrett \& Herbert, 2005). A $10 \mu \mathrm{L}$ reaction mix contained $2.5 \mathrm{mM} \mathrm{MgCl} 2,0.3$ $\mu \mathrm{M}$ of each primer, $0.5 \mathrm{mM}$ dNTPs, and 5 units of Biolase DNA polymerase (Bioline). PCR cycling conditions were as follows: 35 cycles of $30 \mathrm{sec}$ at $95^{\circ} \mathrm{C}, 30 \mathrm{sec}$ at $48^{\circ} \mathrm{C}, 45 \mathrm{sec}$ at $72^{\circ} \mathrm{C}$. PCR products were cleaned with ExoSAP-IT (Affymetrix), Sanger sequenced using Big Dyes (Life Technologies) and run on a 3730xl DNA sequencer (Applied Biosystems). Sequences were examined for quality and trimmed to the standard barcode segment (649 bp) using Sequencher

2045.01 (Gene Codes).

205

206

207

208

209

210

211

212

213

214

215

216

217

\section{Barcode library}

While we targeted 649 bp long DNA barcodes we also submitted (Table 1) 18 shorter fragments ( $>570 \mathrm{bp}$ ) that still satisfy the requirements of The Barcode of Life Data System BOLD systems (Ratnasingham \& Hebert 2007). We combined the 297 species barcodes from this study with publically available Araneae sequences from BOLD retrieved 4 December 2013, for a total of 816 species sequences, which formed the test library for this study. Sequences from BOLD were initially included if the sequence length was at least 600 bases and identification was to species. We further filtered and curated the data to exclude sequences whose identification was anonymous or by non-arachnologists, diverged dramatically from all other spider sequences, or for other reasons the sequences were not deemed to be reliable. After having discarded the above, we did not assess the accuracy of every remaining sequence, as it is well known that both BOLD and GenBank contain errors of various kinds, and we wanted our test library to reflect real world conditions. A single sequence was chosen per species from BOLD using these criteria and added to the original sequences from this project, resulting in 816 species representing 313 genera and 49 families (Table 1 and Supplemental Table 2). Eighteen sequences were singletons at the family level; the maximum number of species per family was 224 . 157 sequences were singletons at the genus level; the maximum number of species per genus was 34 .

224

225

226

227

228

229

230

231

232

233

The standalone BLAST+ suite 2.2.28 (Altschul et al., 1990; Zhang et al., 2000) was used to create a custom BLAST database from these sequences. Each sequence was then queried against the full set using blastn (MegaBLAST task, minimum e value of 1e-10, maximum of top ten hits other than the hit of the query to itself). For each hit the percent of identical nucleotides in the aligned region (PIdent) was calculated by BLAST. An advantage of using BLAST is the local nature of the alignment hits returned. This will account for differences in sequence lengths in the dataset, which may otherwise affect pairwise identity calculations of complete alignments. A possible outcome of BLAST results are short aligned regions that have high similarity but omit much of the queried sequence. To investigate this, we compared lengths of aligned regions with query sequence lengths to determine the prevalence of this in this dataset. Custom Python scripts 
234 (GitHub https://github.com/mkweskin/spider-blast) were used to parse the results, removing the

235

236

237

238

239

240

241

242

243

244

245

246

247

248

249

250

251

252

253

254

255

256

257

258

259

260

261

262

263

264

265

266

267

268

269

270

271

272

273

274

275

match of the query to itself and to score whether hits matched the genus and family of the query sequence or not. Obviously, if the generic identification matched, the family identification also matched; families therefore always match more often than genera.

On the other hand, singleton generic sequences cannot match correctly at the genus level (for spiders or other poorly known diverse groups), and, likewise, singleton family sequences cannot match correctly at the family level (for spiders or other poorly known diverse groups). We included singletons as targets in order to model more realistically BLAST searches against the BOLD database (many sequences in BOLD are higher level singletons), and also to test more strongly the ability of sequences with two or more species per either genus or family to match correctly. Including 18 singleton family sequences and 157 singleton genus sequences, therefore, increases the probability of misidentification at either ranks and more strongly tests the usefulness of barcodes as supraspecific identification tools.

However, because the 18 unique family sequences must fail at both the family and genus levels, and the 157 unique genus level sequences must fail at the genus level, these necessary failures were not included in the overall assessments of the ability of barcode sequences to provide accurate identifications at supraspecific levels.

\section{Results}

The 816 query sequences returned 8159 total hits with one query only returning nine hits and all others ten (Supplemental Table 1). PIdent scores ranged from $75 \%$ to $100 \%$. We also examined the length of the sequence matched compared to the entire sequence length. 8114 hits (>99\%) matched to $90 \%$ or more of the query sequence length indicating that these results represent matches to large portions of the query validating the use of Percent Sequence Identity in the BLAST hits rather than computing the value for a global alignment between sequences. Figure 2 shows the frequency distributions of PIdent values of correct and incorrect identifications at the genus and family rank.

1. $95 \%$ of incorrect genus identifications were below PIdent $=95$ when all hits for all queries are included, which suggests the latter value as a heuristic threshold to delimit incorrect from correct identifications (for these data). For only the highest rank hits whose PIdent $\geq 95,98 \%$ of genus identifications were correct.

2. $95 \%$ of incorrect family identifications were below PIdent $=91$ when all hits for all queries are included, which suggests the latter value as a heuristic threshold to delimit incorrect from correct identifications (for these data). For only the highest rank hits whose PIdent $\geq 91,97 \%$ of family identifications were correct.

3. Library accuracy is crucial, but sequencing, labelling, and identification errors are difficult to detect a priori. The highest ranked incorrect family identification was Meta menardi (Tetragnathidae) to Steatoda grossa (Theridiidae), at PIdent $=96$. Further study of the M. menardi sequence shows that the BOLD record is probably a mislabeled Steatoda. The first true incorrect family identification occurs at a PIdent value of 88; the best hit for Octonoba (Uloboridae) is Amaurobius (Amaurobiidae). 
293

294

295

296

297

298

299

300

301

302

303

304

305

306

307

308

309

310

311

312

313

314

315

316

317

318

319

320

4. For the 136 genera with at least two species in the library, $76 \%(n=103)$ best matched congeners. Thirty-three failed, perhaps because sequences were incorrectly identified taxonomically, or the sequence itself may be erroneous, or perhaps due to nonmonophyly of genera.

5. The distributions of PIdents for correct family and genus identifications differ significantly from the distributions of incorrect identifications (Figure 2).

6. Plotted against increasing numbers of species/genus, and genera/family, the proportion of top ten PIdent values that exceed the above suggested threshold values increases. Roughly speaking, 15 species per genus, and 5 genera per family, are sufficient to ensure that best hits represent correct identifications (Figure 3).

\section{Discussion}

We show that standard DNA barcodes can accurately assign unknown specimens to genus and family given sufficient sequence identity and sufficient taxonomic representation in the database. Accurate identification (PIdent above which less than 5\% of identifications were incorrect) occurred for genera at PIdent values $>95$ and families at PIdent values $\geq 91$, suggesting these as heuristic thresholds for generic and familial identifications in spiders (shaded in Figure 2). Accuracy of identification increases with numbers of species/genus and genera/family; above five genera per family and 15 species per genus all identifications were correct (Figure 3).

The accurate identification of specimens remains a critical challenge for megadiverse groups such as arthropods, most other invertebrates, plants, fungi, protists etc. Morphological identification to species, or even more inclusive taxonomic ranks like genera and families, in many cases requires extensive training, and for most groups taxonomic expertise is limited and dwindling - the so called 'taxonomic impediment' (Rodman \& Cody, 2003). DNA barcodes have been proposed as convenient tools to overcome this impediment by making identification a purely technical procedure available to any interested researcher or even 'citizen scientists'. However, the accuracy of such a tool strongly depends on the scope and quality of the barcode library (Smit, Reijnen \& Stokvis, 2013). Currently available data on databanks like BOLD and GenBank are extensive for some groups, yet the vast majority of species on earth have not yet been barcoded, much less discovered and described taxonomically-each of these tasks is enormous. Even for existing barcoding data, numerous sequences lack accurate taxonomic identification (Collins \& Cruickshank, 2013), limiting their utility (e.g. only 58\% of Araneae in BOLD are identified to species, and of those many are not correctly identified, as shown in our results; see also Shen, Chen \& Murphy, 2013; Blagoev et al., 2016). Therefore, the identification of unknown specimens through blasting against BOLD or GenBank will be inaccurate if the databases lack close hits or contain errors. While the ideal database would allow species-level identification by containing barcodes from expertly identified and vouchered specimens of all species, we hypothesized that rapid surveys of well-known biotas can help quickly to build valuable tools allowing identification of larger clades such as genera and families.

Although we were careful to screen available barcode sequences from BOLD to produce a test library with as few errors as possible, it is certainly possible that errors remained, either due to mistakes in the lab or taxonomic identifications of vouchers. For example, Meta menardi (Tetragnathidae) blasted to Steatoda grossa (Theridiidae) at PIdent $=96$, and BLAST searches on GenBank suggest this Meta sequence is actually a Steatoda. Likewise, the linyphiids Agyneta 
321

322

323

324

325

326

327

328

329

330

331

332

333

334

335

336

337

338

339

340

341

342

343

344

345

346

347

348

349

350

351

352

353

354

355

356

357

358

359

360

361

362

orites and Incestophantes frigidus sequences were identical; one of these records is probably wrong. These sorts of errors bias identifications and limit utility of barcodes. Other examples of identical barcode sequences were all congeners, and therefore are less likely to involve errors but could indicate faults in taxonomy: Arctosa maculata and A. fulvolineata, Bolyphantes luteolus and B. alticeps, Pardosa alacris and P. trifrons, and Pityohyphantes tacoma and P. cristatus. Likewise, the genus Neriene (Linyphiidae) seems non-monophyletic and identifications were thus not accurate.

\section{Conclusions}

These results suggest that accurate assignment of unknown taxa to genus and family is feasible through DNA barcoding. Database quality is crucial. Numbers of potential matches at generic and familial ranks also affect the probability that an unknown sequence will blast best to the correct family or genus. Unlike the inventory of species, biological discovery of family-level clades of life also seems far advanced - few eukaryotic families, apparently, remain to be discovered. Taken together, these results suggest that barcode-targeted sequencing of exemplars from all families of life (and most genera, if possible) should be an important scientific priority. It would enable approximate taxonomic identification of any organism anywhere on Earth by rapid, cheap, purely technical procedures requiring no specialist knowledge - certainly an important milestone in the on-going attempt to discover, classify, and understand the Earth's biota.

\section{Acknowledgements}

Portions of the laboratory and/or computer work were conducted in and with the support of the L.A.B. facilities of the National Museum of Natural History.

\section{References}

Altschul SF, Gish W, Miller W, Myers EW, Lipman DJ. 1990. Basic local alignment search tool. Journal of Molecular Biology 215:403-410.

Anslan S, Tedersoo L. 2015. Performance of cytochrome c oxidase subunit I (COI), ribosomal DNA Large Subunit (LSU) and Internal Transcribed Spacer 2 (ITS2) in DNA barcoding of Collembola. European Journal of Soil Biology 69:1-7. DOI: 10.1016/j.ejsobi.2015.04.001.

Barraclough TG, Hughes M, Ashford-Hodges N, Fujisawa T. 2009. Inferring evolutionarily significant units of bacterial diversity from broad environmental surveys of single-locus data. Biology Letters 5:425-428. DOI: 10.1098/rsbl.2009.0091.

Barrett RDH, Hebert PDN. 2005. Identifying spiders through DNA barcodes. Canadian Journal of Zoology-Revue Canadienne De Zoologie 83:481-491. DOI: 10.1139/z05-024.

Blagoev GA, Dewaard JR, Ratnasingham S, Dewaard SL, Lu L, Robertson J, Telfer AC, Hebert PDN. 2016. Untangling taxonomy: A DNA barcode reference library for Canadian spiders. Molecular Ecology Resources 16:325-341. DOI: 10.1111/1755-0998.12444. 
363 Čandek K, Gregorič M, Kostanjšek R, Frick H, Kropf C, Kuntner M. 2013. Targeting a portion

364 of central European spider diversity for permanent preservation. Biodiversity Data

365

366 Journal 1:e980. DOI: 10.3897/BDJ.1.e980.

Čandek K, Gregorič M, Kostanjšek R, Frick H, Kropf C, Kuntner M. 2015. Corrigendum: Targeting a portion of central European spider diversity for permanent preservation. Biodiversity Data Journal 3:e4301. DOI: 10.3897/BDJ.3.e4301.

Čandek K, Kuntner M. 2015. DNA barcoding gap: Reliable species identification over morphological and geographical scales. Molecular Ecology Resources 15:268-277. DOI: 10.1111/1755-0998.12304.

Chase MW, Fay MF. 2009. Barcoding of plants and fungi. Science 325:682-683. DOI: 10.1126/science.1176906.

Clerck C. 1757. Aranei Suecici, descriptionibus et figuris oeneis illustrati,ad genera subalterna redacti speciebus ultra LX determinati. Svenska Spindlar,uti sina hufvud-slagter undelte samt.. Stockholmiae: [Publ. not given].

Coddington JA, Levi HW. 1991. Systematics and evolution of spiders (Araneae). Annual Review of Ecology and Systematics 22:565-592. DOI: 10.1146/annurev.es.22.110191.003025.

Collins RA, Cruickshank RH. 2013. The seven deadly sins of DNA barcoding. Molecular Ecology Resources 13:969-975. DOI: 10.1111/1755-0998.12046.

Doña J, Diaz-Real J, Mironov S, Bazaga P, Serrano D, Jovani R. 2015. DNA barcoding and minibarcoding as a powerful tool for feather mite studies. Molecular Ecology Resources 15:1216-1225. DOI: 10.1111/1755-0998.12384.

Edgar RC. 2010. Search and clustering orders of magnitude faster than BLAST. Bioinformatics 26:2460-2461. DOI: 10.1093/bioinformatics/btq461.

Erwin TL. 1982. Tropical forests: Their richness in Coleoptera and other arthropod species. The Coleopterists Bull 36(1):74-75.

Folmer O, Black M, Hoeh W, Lutz R, Vrijenhoek R. 1994. DNA primers for amplification of mitochondrial cytochrome c oxidase subunit I from diverse metazoan invertebrates. Molecular Marine Biology and Biotechnology 3:294-299.

Forster RR. 1955. A new family of spiders of the sub-order Hypochilomorphae. Pacific Science 9:277-285.

Goloboff PA, Catalano SA, Mirande JM, Szumik CA, Arias JS, Kallersjo M, Farris JS. 2009. Phylogenetic analysis of 73060 taxa corroborates major eukaryotic groups. Cladistics 25:211-230. DOI: 10.1111/j.1096-0031.2009.00255.x.

Hebert PDN, Cywinska A, Ball SL, DeWaard JR. 2003. Biological identifications through DNA barcodes. Proceedings of the Royal Society of London Series B-Biological Sciences 270:313-321. DOI: 10.1098/rspb.2002.2218.

Huson DH, Auch AF, Qi J, Schuster SC. 2007. MEGAN analysis of metagenomic data. Genome Research 17:377-386. DOI: 10.1101/gr.5969107.

Kearse M, Moir R, Wilson A, Stones-Havas S, Cheung M, Sturrock S, Buxton S, Cooper A, Markowitz S, Duran C, Thierer T, Ashton B, Mentjies P, Drummond A. 2012. Geneious Basic: An integrated and extendable desktop software platform for the organization and analysis of sequence data. Bioinformatics, 28, 1647-1649. DOI: 10.1093/bioinformatics/bts199.

Kress WJ, Erickson DL. 2007. A two-locus global DNA barcode for land plants: the coding rbcL gene complements the non-coding trnH-psbA spacer region. PLOS ONE 2(6):e508. DOI: 10.1371/journal.pone.0000508. 
409

410

411

412

413

414

415

416

417

418

419

420

421

422

423

424

425

426

427

428

429

430

431

432

433

434

435

436

437

438

439

440

441

442

443

444

445

446

447

448

449

450

451

452

453
Linnaeus C. 1758. Systema Naturae per regna tria naturae, secundum classes, ordines, genera, species cum characteribus differentiis, synonymis, locis. Editio decima, reformata. Holmiae, tomus 1:1-821: [Publ. not given].

Liu Y, Yan HF, Cao T, Ge XJ. 2010. Evaluation of 10 plant barcodes in Bryophyta (Mosses). Journal of Systematics and Evolution 48:36-46. DOI: 10.1111/j.1759-6831.2009.00063.x.

Lopardo L, Uhl G. 2014. Testing mitochondrial marker efficacy for DNA barcoding in spiders: a test case using the dwarf spider genus Oedothorax (Araneae: Linyphiidae: Erigoninae). Invertebrate Systematics 28:501-521. DOI: 10.1071/IS14017.

May RM. 1992. How many species inhabit the earth. Scientific American 1992:42-48.

Meyer CP, Paulay G. 2005. DNA barcoding: Error rates based on comprehensive sampling. PLoS Biology 3(12):e422. DOI: 10.1371/journal.pbio.0030422.

Mora C, Tittensor DP, Adl S, Simpson AG, and Worm B. 2011. How many species are there on Earth and in the ocean? PLoS Biology 9(8):e1001127. DOI: 10.1371/journal.pbio.1001127.

Nagy ZT, Sonet G, Glaw F, and Vences M. 2012. First large-scale DNA barcoding assessment of reptiles in the biodiversity hotspot of Madagascar, based on newly designed COI primers. PLoS ONE 7(3):e34506. DOI: 10.1371/journal.pone.0034506.

Nitta JH. 2008. Exploring the utility of three plastid loci for biocoding the filmy ferns (Hymenophyllaceae) of Moorea. Taxon 57:725-736.

Pentinsaari M, Hebert PDN, Mutanen M. 2014. Barcoding beetles: A regional survey of 1872 species reveals high identification success and unusually deep interspecific divergences. PLoS ONE 9(9):e108651. DOI: 10.1371/journal.pone.0108651.

Pyron RA, Wiens JJ. 2011. A large-scale phylogeny of Amphibia including over 2800 species, and a revised classification of extant frogs, salamanders, and caecilians. Molecular Phylogenetics and Evolution 61:543-583. DOI: 10.1016/j.ympev.2011.06.012.

Ratnasingham S, Hebert PDN. 2007. BOLD: The Barcode of Life Data System (www.barcodinglife.org). Molecular Ecology Notes 7:355-364. DOI: 10.1111/j.14718286.2007.01678.x.

Rodman JE, Cody JH. 2003. The taxonomic impediment overcome: NSF's partnerships for enhancing expertise in taxonomy (PEET) as a model. Systematic Biology 52:428-435. DOI: $10.1080 / 10635150390197055$.

Saunders GW. 2005. Applying DNA barcoding to red macroalgae: A preliminary appraisal holds promise for future applications. Philosophical Transactions of the Royal Society BBiological Sciences 360:1879-1888. DOI: 10.1098/rstb.2005.1719.

Scicluna SM, Tawari B, Clark CG. 2006. DNA barcoding of Blastocystis. Protist 157:77-85. DOI: $10.1016 /$ j.protis.2005.12.001.

Shen YY, Chen X, Murphy RW. 2013. Assessing DNA barcoding as a tool for species identification and data quality control. PLoS ONE 8(2):e57125. DOI: 10.1371/journal.pone.0057125.

Smit J, Reijnen B, Stokvis F. 2013. Half of the European fruit fly species barcoded (Diptera, Tephritidae); a feasibility test for molecular identification. ZooKeys 365:279-305. DOI: 10.3897/zookeys.365.5819.

Wang Q, Garrity GM, Tiedje JM, Cole JR. 2007. Naïve bayesian classifier for rapid assignment of rRNA sequences into the new bacterial taxonomy. Applied and Environmental Microbiology 73:5261-5267. DOI: 10.1128/AEM.00062-07. 
454 Wang XB, Deng J, Zhang JT, Zhou QS, Zhang YZ, Wu SA. 2015. DNA barcoding of common

455

456

457

458

459

460

461

462

463

464

465

466

467

468 soft scales (Hemiptera: Coccoidea: Coccidae) in China. Bulletin of Entomological Research 105(5):545-554. DOI: 10.1017/S0007485315000413.

Wilson JJ, Rougerie R, Schonfeld J, Janzen DH, Hallwachs W, Hajibabaei M, Kitching IJ, Haxaire J, Hebert PDN. 2011. When species matches are unavailable are DNA barcodes correctly assigned to higher taxa? An assessment using sphingid moths. Bmc Ecology 11:18. DOI: $10.1186 / 1472-6785-11-18$.

Xu X, Liu F, Chen J, Li D, Kuntner M. 2015. Integrative taxonomy of the primitively segmented spider genus Ganthela (Araneae: Mesothelae: Liphistiidae): DNA barcoding gap agrees with morphology. Zoological Journal of the Linnean Society 175:288-306. DOI: 10.1111/zoj.12280.

Zhang Z, Schwartz S, Wagner L, Miller W. 2000. A greedy algorithm for aligning DNA sequences. Journal of Computational Biology 7:203-214. DOI: 10.1089/10665270050081478. 
469

470

471

472

473

474

475

476

477

478

479

480

481

482

483

484

485

486

487

488

489

490

491

492

493

494

495

496

497

498

499

\section{FIGURES}

Figure 1. Accumulation curve of dates of first discovery (year of first description of a contained species) of families for six major clades of life, 1758-2010.

Figure 2. Frequency distributions of correct and incorrect identifications by percent sequence identity (PIdent) for the top ten hits (all ranks) and for best hits only (top rank) at the genus and family level. Shaded areas include hits where no more than $5 \%$ of identifications were incorrect.

Figure 3. Relation between proportion of best sequence identity and numbers of species per genus (A), and genera per family (B). Heuristic thresholds to delimit incorrect from correct identifications were 95 and 91 for genus and family, respectively.

\section{TABLES}

Table 1. Original sequences this project submitted to BOLD and GenBank (only those on GenBank are also publically available on BOLD, for all others, see http://ezlab.zrc-sazu.si/dna/). Legend: MNH, SI = National Museum of Natural History, Smithsonian Institution; EZ LAB = Evolutionary Zoology Lab, ZRC SAZU; NMBE = Naturhistorisches Museum der Burgergemeinde Bern; SVN = Slovenia; $\mathrm{CHE}=$ Switzerland; MYS = Malaysia.

See separate Excel file.

\section{SUPPLEMENTS (AVAILABLE ONLINE)}

Supplemental Table 1. The results of the barcode matching test.

Supplemental Table 2. The downloaded sequences used in the species comparison. 


\section{1}

First discovery of major clades of life.

Figure 1. Accumulation curve of dates of first discovery (year of first description of a contained species) of families for six major clades of life, 1758-2010.

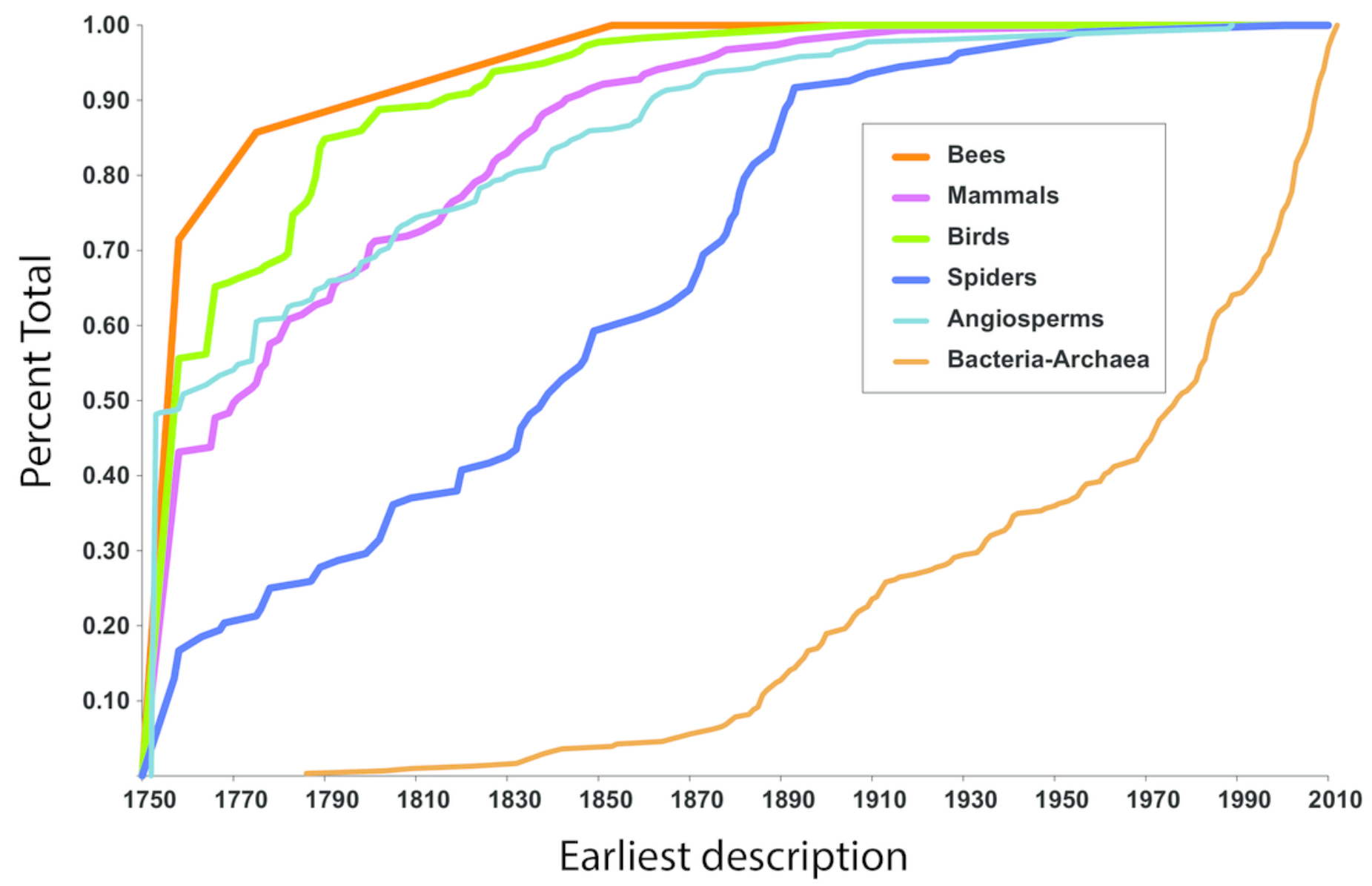


2

Results form the barcode matching test.

Figure 2. Frequency distributions of correct and incorrect identifications by percent sequence identity (PIdent) for the top ten and/or best hits at the genus and family level. Shaded areas include hits where no more than $5 \%$ of identifications were incorrect.
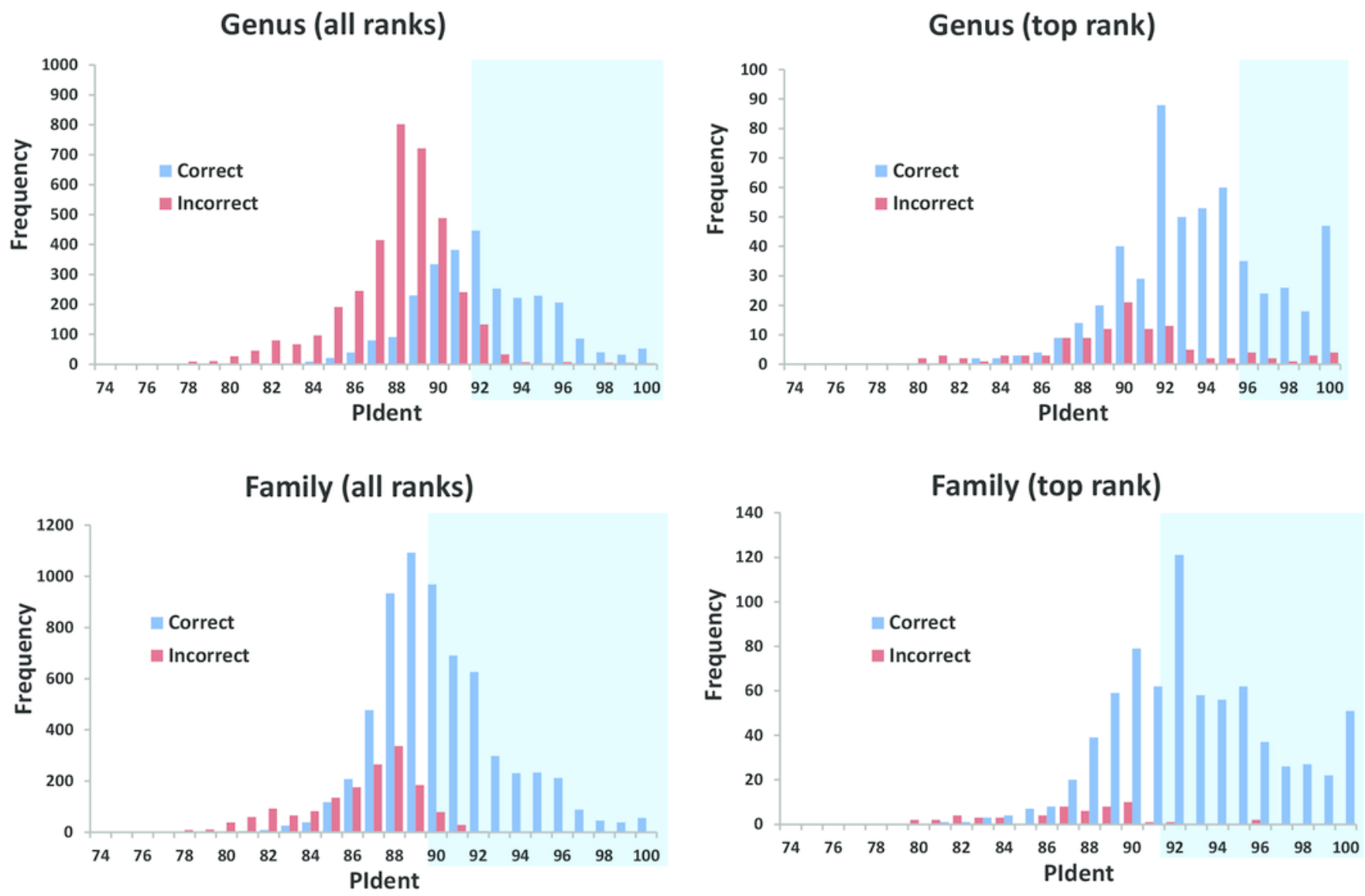


\section{Table $\mathbf{1}$ (on next page)}

Table1.docx 


$\begin{array}{ll}\text { Family } & \text { Genus } \\ \text { Agelenidae } & \text { Agelena } \\ \text { Agelenidae } & \text { Agelena } \\ \text { Agelenidae } & \text { Allagelena } \\ \text { Agelenidae } & \text { Coelotes } \\ \text { Agelenidae } & \text { Histopona } \\ \text { Agelenidae } & \text { Histopona } \\ \text { Agelenidae } & \text { Inermocoelotes } \\ \text { Agelenidae } & \text { Inermocoelotes } \\ \text { Agelenidae } & \text { Malthonica } \\ \text { Agelenidae } & \text { Malthonica } \\ \text { Agelenidae } & \text { Tegenaria } \\ \text { Agelenidae } & \text { Tegenaria } \\ \text { Amaurobiidae } & \text { Amaurobius } \\ \text { Amaurobiidae } & \text { Amaurobius } \\ \text { Amaurobiidae } & \text { Amaurobius } \\ \text { Amaurobiidae } & \text { Amaurobius } \\ \text { Amaurobiidae } & \text { Amaurobius } \\ \text { Anyphaenidae } & \text { Anyphaena } \\ \text { Anyphaenidae } & \text { Anyphaena } \\ \text { Araneidae } & \text { Aculepeira } \\ \text { Araneidae } & \text { Aculepeira } \\ \text { Araneidae } & \text { Agalenatea } \\ \text { Araneidae } & \text { Agalenatea } \\ \text { Araneidae } & \text { Araneus } \\ \text { Araneidae } & \text { Araneus } \\ \text { Araneidae } & \text { Araneus } \\ \text { Araneidae } & \text { Araneus } \\ \text { Araneidae } & \text { Araneus } \\ & \end{array}$

Species
labyrinthica
labyrinthica
gracilens
terrestris
torpida
torpida
anoplus
anoplus
silvestris
silvestris
atrica
atrica
erberi
erberi
fenestralis
ferox
jugorum
accentuata
sabina
ceropegia
ceropegia
redii
redii
alsine
angulatus
angulatus
diadematus
diadematus

\begin{tabular}{ll} 
Sample ID & Process ID \\
00786574 & SPSLO002-12 \\
ARA0239 & SPSLO369-13 \\
00786557 & SPSLO001-12 \\
00786563 & SPSLO003-12 \\
00786599 & SPSLO004-12 \\
ARA0063 & SPSLO339-13 \\
00786586 & SPSLO005-12 \\
ARA0339 & SPSLO392-13 \\
00786304 & SPSLO283-13 \\
ARA0427 & SPSLO468-13 \\
00786583 & SPSLO006-12 \\
ARA0076 & SPSLO341-13 \\
00786571 & SPSLO007-12 \\
ARA0120 & SPSLO347-13 \\
00786389 & SPSLO189-12 \\
00786307 & SPSLO284-13 \\
00786585 & SPSLO008-12 \\
00786584 & SPSLO009-12 \\
00786551 & SPSLO010-12 \\
00786570 & SPSLO011-12 \\
ARA0355 & SPSLO405-13 \\
00786368 & SPSLO095-12 \\
ARA0381 & SPSLO429-13 \\
00786568 & SPSLO012-12 \\
00786552 & SPSLO013-12 \\
ARA0001 & SPSLO326-13 \\
00786593 & SPSLO014-12 \\
ARA0050 & SPSLO336-13 \\
& \\
\hline $0 X X X X$
\end{tabular}

GenBank

accession Voucher number stored at

$\mathrm{MNH}, \mathrm{SI}$

EZ LAB

KX039062 MNH, SI

KX039130 MNH, SI

KX039207 MNH, SI

KX039208 EZ LAB

KX039220 MNH, SI

KX039219 EZ LAB

KX039239 MNH, SI

KX039238 EZ LAB

KX039170 MNH, SI

KX039169 EZ LAB

KX039070 MNH, SI

KX039069 EZ LAB

KX039071 MNH, SI

KX039072 MNH, SI

KX039073 MNH, SI

KX039076 MNH, SI

KX039077 MNH, SI

KX039041 MNH, SI

KX039040 NMBE

KX039043 MNH, SI

KX039042 EZ LAB

KX039079 MNH, SI

KX039081 MNH, SI

KX039080 EZ LAB

KX039083 MNH, SI

KX039082 EZ LAB

\section{Collected in}

SVN

SVN

SVN

SVN

SVN

SVN

SVN

SVN

SVN

SVN

SVN

SVN

SVN

SVN

CHE

SVN

SVN

SVN

SVN

SVN

CHE

SVN

SVN

SVN

SVN

SVN

SVN

SVN 


\begin{tabular}{|c|c|c|c|c|c|c|c|}
\hline Araneidae & Araneus & marmoreus & 00786575 & SPSLO015-12 & KX039085 & $\mathrm{MNH}, \mathrm{SI}$ & SVN \\
\hline Araneidae & Araneus & marmoreus & ARA0030 & SPSLO329-13 & KX039084 & EZ LAB & SVN \\
\hline Araneidae & Araneus & quadratus & 00786572 & SPSLO016-12 & KX039086 & $\mathrm{MNH}, \mathrm{SI}$ & SVN \\
\hline Araneidae & Araneus & quadratus & ARA0198 & SPSLO362-13 & KX039087 & NMBE & $\mathrm{CHE}$ \\
\hline Araneidae & Araneus & sturmi & 00786561 & SPSLO017-12 & KX039089 & $\mathrm{MNH}, \mathrm{SI}$ & SVN \\
\hline Araneidae & Araneus & sturmi & ARA0108 & SPSLO345-13 & KX039088 & EZ LAB & SVN \\
\hline Araneidae & Araniella & cucurbitina & 00786596 & SPSLO018-12 & KX039090 & $\mathrm{MNH}, \mathrm{SI}$ & SVN \\
\hline Araneidae & Araniella & opisthographa & ARA0393 & SPSLO440-13 & KX039091 & EZ LAB & SVN \\
\hline Araneidae & Argiope & bruennichi & 00786589 & SPSLO019-12 & KX039093 & $\mathrm{MNH}, \mathrm{SI}$ & SVN \\
\hline Araneidae & Argiope & bruennichi & ARA0048 & SPSLO335-13 & KX039094 & EZ LAB & SVN \\
\hline Araneidae & Cercidia & prominens & 00786498 & SPSLO021-12 & KX039116 & $\mathrm{MNH}, \mathrm{SI}$ & SVN \\
\hline Araneidae & Cercidia & prominens & 00786577 & SPSLO020-12 & KX039114 & $\mathrm{MNH}, \mathrm{SI}$ & SVN \\
\hline Araneidae & Cercidia & prominens & ARA0356 & SPSLO406-13 & KX039115 & EZ LAB & SVN \\
\hline Araneidae & Cyclosa & conica & 00786573 & SPSLO022-12 & KX039135 & MNH, SI & SVN \\
\hline Araneidae & Cyclosa & conica & ARA0380 & SPSLO428-13 & KX039136 & NMBE & $\mathrm{CHE}$ \\
\hline Araneidae & Gibbaranea & bituberculata & 00786579 & SPSLO023-12 & KX039186 & $\mathrm{MNH}, \mathrm{SI}$ & SVN \\
\hline Araneidae & Gibbaranea & bituberculata & ARA0350 & SPSLO400-13 & KX039187 & EZ LAB & SVN \\
\hline Araneidae & Hypsosinga & albovittata & 00786323 & SPSLO191-12 & KX039211 & $\mathrm{MNH}, \mathrm{SI}$ & $\mathrm{CHE}$ \\
\hline Araneidae & Hypsosinga & pygmaea & 00786555 & SPSLO024-12 & KX039212 & $\mathrm{MNH}, \mathrm{SI}$ & SVN \\
\hline Araneidae & Hypsosinga & sanguinea & 00786314 & SPSLO285-13 & KX039213 & $\mathrm{MNH}, \mathrm{SI}$ & SVN \\
\hline Araneidae & Hypsosinga & sanguinea & ARA0370 & SPSLO419-13 & KX039214 & NMBE & $\mathrm{CHE}$ \\
\hline Araneidae & Larinioides & sclopetarius & 00786382 & SPSLO096-12 & KX039222 & $\mathrm{MNH}, \mathrm{SI}$ & SVN \\
\hline Araneidae & Leviellus & thorelli & 00786591 & SPSLO025-12 & KX039229 & $\mathrm{MNH}, \mathrm{SI}$ & SVN \\
\hline Araneidae & Leviellus & thorelli & ARA0353 & SPSLO403-13 & KX039228 & EZ LAB & SVN \\
\hline Araneidae & Mangora & acalypha & 00786590 & SPSLO026-12 & KX039242 & $\mathrm{MNH}, \mathrm{SI}$ & SVN \\
\hline Araneidae & Mangora & acalypha & ARA0107 & SPSLO344-13 & KX039240 & EZ LAB & SVN \\
\hline Araneidae & Mangora & acalypha & ARA0357 & SPSLO407-13 & KX039241 & EZ LAB & SVN \\
\hline Araneidae & Neoscona & adianta & 00786330 & SPSLO192-12 & KX039282 & $\mathrm{MNH}, \mathrm{SI}$ & SVN \\
\hline Araneidae & Nuctenea & umbratica & 00786594 & SPSLO027-12 & KX039293 & $\mathrm{MNH}, \mathrm{SI}$ & SVN \\
\hline Araneidae & Nuctenea & umbratica & ARA0387 & SPSLO435-13 & KX039292 & NMBE & $\mathrm{CHE}$ \\
\hline Araneidae & Parazygiella & montana & 00786582 & SPSLO028-12 & KX039307 & $\mathrm{MNH}, \mathrm{SI}$ & SVN \\
\hline
\end{tabular}




\begin{tabular}{|c|c|c|c|c|c|c|c|}
\hline Araneidae & Parazygiella & montana & ARA0354 & SPSLO404-13 & KX039308 & NMBE & $\mathrm{CHE}$ \\
\hline Araneidae & Singa & nitidula & 00786597 & SPSLO029-12 & KX039376 & $\mathrm{MNH}, \mathrm{SI}$ & SVN \\
\hline Araneidae & Stroemiellus & stroemi & ARA0169 & SPSLO358-13 & KX039383 & EZ LAB & SVN \\
\hline Araneidae & Zilla & diodia & 00786481 & SPSLO097-12 & KX039446 & $\mathrm{MNH}, \mathrm{SI}$ & SVN \\
\hline Araneidae & Zilla & diodia & ARA0342 & SPSLO393-13 & KX039447 & EZ LAB & SVN \\
\hline Araneidae & Zygiella & x-notata & 00786326 & SPSLO193-12 & KX039450 & $\mathrm{MNH}, \mathrm{SI}$ & CHE \\
\hline Atypidae & Atypus & piceus & 00786580 & SPSLO031-12 & KX039096 & $\mathrm{MNH}, \mathrm{SI}$ & SVN \\
\hline Atypidae & Atypus & piceus & ARA0174 & SPSLO359-13 & KX039097 & EZ LAB & SVN \\
\hline Clubionidae & Clubiona & germanica & 00786566 & SPSLO032-12 & KX039122 & $\mathrm{MNH}, \mathrm{SI}$ & SVN \\
\hline Clubionidae & Clubiona & kulczynskii & 00786404 & SPSLO194-12 & KX039123 & $\mathrm{MNH}, \mathrm{SI}$ & $\mathrm{CHE}$ \\
\hline Clubionidae & Clubiona & neglecta & 00786558 & SPSLO033-12 & KX039124 & $\mathrm{MNH}, \mathrm{SI}$ & SVN \\
\hline Clubionidae & Clubiona & pseudoneglecta & 00786286 & SPSLO286-13 & KX039125 & $\mathrm{MNH}, \mathrm{SI}$ & SVN \\
\hline Clubionidae & Clubiona & reclusa & 00786378 & SPSLO195-12 & KX039126 & $\mathrm{MNH}, \mathrm{SI}$ & CHE \\
\hline Clubionidae & Clubiona & reclusa & ARA0371 & SPSLO420-13 & KX039127 & NMBE & $\mathrm{CHE}$ \\
\hline Clubionidae & Clubiona & terrestris & 00786457 & SPSLO098-12 & KX039129 & $\mathrm{MNH}, \mathrm{SI}$ & SVN \\
\hline Clubionidae & Clubiona & terrestris & ARA0242 & SPSLO371-13 & KX039128 & EZ LAB & SVN \\
\hline Corinnidae & Phrurolithus & minimus & 00786559 & SPSLO034-12 & KX039341 & $\mathrm{MNH}, \mathrm{SI}$ & SVN \\
\hline Dictynidae & Argenna & subnigra & 00786283 & SPSLO288-13 & & $\mathrm{MNH}, \mathrm{SI}$ & SVN \\
\hline Dictynidae & Cicurina & cicur & 00786548 & SPSLO035-12 & KX039121 & $\mathrm{MNH}, \mathrm{SI}$ & SVN \\
\hline Dictynidae & Dictyna & arundinacea & 00786369 & SPSLO196-12 & KX039140 & $\mathrm{MNH}, \mathrm{SI}$ & $\mathrm{CHE}$ \\
\hline Dictynidae & Dictyna & arundinacea & ARA0379 & SPSLO427-13 & KX039139 & NMBE & $\mathrm{CHE}$ \\
\hline Dictynidae & Dictyna & civica & 00786511 & SPSLO036-12 & KX039141 & $\mathrm{MNH}, \mathrm{SI}$ & SVN \\
\hline Dictynidae & Dictyna & uncinata & 00786345 & SPSLO197-12 & KX039143 & $\mathrm{MNH}, \mathrm{SI}$ & SVN \\
\hline Dictynidae & Dictyna & uncinata & ARA0423 & SPSLO466-13 & KX039142 & EZ LAB & SVN \\
\hline Dictynidae & Lathys & humilis & 00786473 & SPSLO198-12 & KX039224 & $\mathrm{MNH}, \mathrm{SI}$ & SVN \\
\hline Dictynidae & Lathys & humilis & 00786550 & SPSLO037-12 & KX039223 & $\mathrm{MNH}, \mathrm{SI}$ & SVN \\
\hline Dysderidae & Dasumia & canestrinii & 00786581 & SPSLO038-12 & KX039137 & $\mathrm{MNH}, \mathrm{SI}$ & SVN \\
\hline Dysderidae & Dysdera & adriatica & 00786287 & SPSLO289-13 & KX039154 & $\mathrm{MNH}, \mathrm{SI}$ & SVN \\
\hline Dysderidae & Dysdera & adriatica & 00786296 & SPSLO290-13 & KX039155 & $\mathrm{MNH}, \mathrm{SI}$ & SVN \\
\hline Dysderidae & Dysdera & ninnii & ARA0244 & SPSLO373-13 & KX039156 & EZ LAB & SVN \\
\hline Filistatidae & Filistata & insidiatrix & 00786560 & SPSLO040-12 & KX039181 & $\mathrm{MNH}, \mathrm{SI}$ & SVN \\
\hline
\end{tabular}




\begin{tabular}{|c|c|c|c|c|c|c|c|}
\hline Filistatidae & Filistata & insidiatrix & ARA0122 & SPSLO348-13 & KX039182 & EZ LAB & SVN \\
\hline Gnaphosidae & Aphantaulax & cincta & 00786470 & SPSL0199-12 & KX039078 & $\mathrm{MNH}, \mathrm{SI}$ & SVN \\
\hline Gnaphosidae & Callilepis & schuszteri & 00786553 & SPSLO041-12 & KX039103 & $\mathrm{MNH}, \mathrm{SI}$ & SVN \\
\hline Gnaphosidae & Callilepis & schuszteri & ARA0333 & SPSLO386-13 & KX039102 & EZ LAB & SVN \\
\hline Gnaphosidae & Drassodes & lapidosus & 00786505 & SPSLO099-12 & KX039150 & $\mathrm{MNH}, \mathrm{SI}$ & SVN \\
\hline Gnaphosidae & Drassodes & pubescens & 00786273 & SPSLO291-13 & KX039151 & $\mathrm{MNH}, \mathrm{SI}$ & SVN \\
\hline Gnaphosidae & Drassyllus & villicus & 00786556 & SPSLO042-12 & KX039153 & $\mathrm{MNH}, \mathrm{SI}$ & SVN \\
\hline Gnaphosidae & Drassyllus & villicus & ARA0337 & SPSLO390-13 & KX039152 & EZ LAB & SVN \\
\hline Gnaphosidae & Gnaphosa & bicolor & 00786276 & SPSLO292-13 & KX039188 & $\mathrm{MNH}, \mathrm{SI}$ & SVN \\
\hline Gnaphosidae & Haplodrassus & silvestris & 00786578 & SPSLO043-12 & KX039196 & $\mathrm{MNH}, \mathrm{SI}$ & SVN \\
\hline Gnaphosidae & Micaria & aenea & 00786384 & SPSLO200-12 & KX039258 & $\mathrm{MNH}, \mathrm{SI}$ & $\mathrm{CHE}$ \\
\hline Gnaphosidae & Micaria & pulicaria & 00786274 & SPSLO293-13 & KX039259 & $\mathrm{MNH}, \mathrm{SI}$ & SVN \\
\hline Gnaphosidae & Nomisia & exornata & 00786564 & SPSLO044-12 & KX039291 & $\mathrm{MNH}, \mathrm{SI}$ & SVN \\
\hline Gnaphosidae & Phaeocedus & braccatus & 00786592 & SPSLO045-12 & KX039330 & $\mathrm{MNH}, \mathrm{SI}$ & SVN \\
\hline Gnaphosidae & Scotophaeus & scutulatus & 00786576 & SPSLO046-12 & KX039369 & $\mathrm{MNH}, \mathrm{SI}$ & SVN \\
\hline Gnaphosidae & Scotophaeus & scutulatus & ARA0082 & SPSL0343-13 & KX039370 & EZ LAB & SVN \\
\hline Gnaphosidae & Trachyzelotes & pedestris & 00786279 & SPSLO294-13 & KX039419 & $\mathrm{MNH}, \mathrm{SI}$ & SVN \\
\hline Gnaphosidae & Zelotes & apricorum & 00786278 & SPSLO295-13 & KX039441 & $\mathrm{MNH}, \mathrm{SI}$ & SVN \\
\hline Gnaphosidae & Zelotes & latreillei & 00786540 & SPSLO047-12 & KX039443 & $\mathrm{MNH}, \mathrm{SI}$ & SVN \\
\hline Gnaphosidae & Zelotes & latreillei & ARA0191 & SPSLO360-13 & KX039442 & EZ LAB & SVN \\
\hline Gnaphosidae & Zelotes & subterraneus & 00786588 & SPSLO048-12 & KX039445 & $\mathrm{MNH}, \mathrm{SI}$ & $\mathrm{CHE}$ \\
\hline Gnaphosidae & Zelotes & subterraneus & ARA0156 & SPSLO355-13 & KX039444 & NMBE & $\mathrm{CHE}$ \\
\hline Hahniidae & Antistea & elegans & 00786405 & SPSLO201-12 & KX039075 & $\mathrm{MNH}, \mathrm{SI}$ & $\mathrm{CHE}$ \\
\hline Hahniidae & Antistea & elegans & ARA0384 & SPSLO432-13 & KX039074 & NMBE & $\mathrm{CHE}$ \\
\hline Hahniidae & Hahnia & difficilis & 00786363 & SPSLO202-12 & KX039195 & $\mathrm{MNH}, \mathrm{SI}$ & $\mathrm{CHE}$ \\
\hline Hahniidae & Hahnia & difficilis & ARA0399 & SPSLO445-13 & KX039194 & NMBE & $\mathrm{CHE}$ \\
\hline Linyphiidae & Agnyphantes & expunctus & 00786328 & SPSLO203-12 & KX039044 & $\mathrm{MNH}, \mathrm{SI}$ & $\mathrm{CHE}$ \\
\hline Linyphiidae & Agnyphantes & expunctus & ARA0429 & SPSLO470-13 & KX039045 & NMBE & $\mathrm{CHE}$ \\
\hline Linyphiidae & Agyneta & affinis & 00786439 & SPSLO115-12 & KX039049 & $\mathrm{MNH}, \mathrm{SI}$ & $\mathrm{CHE}$ \\
\hline Linyphiidae & Agyneta & affinis & ARA0245 & SPSLO374-13 & KX039048 & NMBE & $\mathrm{CHE}$ \\
\hline Linyphiidae & Agyneta & alpica & 00786443 & SPSLO116-12 & KX039050 & $\mathrm{MNH}, \mathrm{SI}$ & $\mathrm{CHE}$ \\
\hline
\end{tabular}




\begin{tabular}{|c|c|c|c|c|c|c|c|}
\hline Linyphiidae & Agyneta & cauta & 00786426 & SPSLO204-12 & KX039052 & $\mathrm{MNH}, \mathrm{SI}$ & $\mathrm{CHE}$ \\
\hline Linyphiidae & Agyneta & cauta & ARA0225 & SPSLO367-13 & KX039051 & NMBE & $\mathrm{CHE}$ \\
\hline Linyphiidae & Agyneta & conigera & 00786448 & SPSLO100-12 & KX039053 & $\mathrm{MNH}, \mathrm{SI}$ & CHE \\
\hline Linyphiidae & Agyneta & fuscipalpa & 00786425 & SPSLO218-12 & & $\mathrm{MNH}, \mathrm{SI}$ & CHE \\
\hline Linyphiidae & Agyneta & fuscipalpa & ARA0268 & SPSLO378-13 & & NMBE & $\mathrm{CHE}$ \\
\hline Linyphiidae & Agyneta & gulosa & 00786464 & SPSLO219-12 & KX039054 & $\mathrm{MNH}, \mathrm{SI}$ & $\mathrm{CHE}$ \\
\hline Linyphiidae & Agyneta & innotabilis & 00786393 & SPSLO220-12 & KX039055 & $\mathrm{MNH}, \mathrm{SI}$ & $\mathrm{CHE}$ \\
\hline Linyphiidae & Agyneta & orites & 00786419 & SPSLO221-12 & KX039057 & $\mathrm{MNH}, \mathrm{SI}$ & CHE \\
\hline Linyphiidae & Agyneta & orites & ARA0403 & SPSLO449-13 & KX039056 & NMBE & $\mathrm{CHE}$ \\
\hline Linyphiidae & Agyneta & rurestris & 00786411 & SPSLO117-12 & KX039058 & $\mathrm{MNH}, \mathrm{SI}$ & $\mathrm{CHE}$ \\
\hline Linyphiidae & Agyneta & rurestris & ARA0419 & SPSLO462-13 & KX039059 & EZ LAB & SVN \\
\hline Linyphiidae & Agyneta & saxatilis & 00786277 & SPSLO298-13 & KX039060 & $\mathrm{MNH}, \mathrm{SI}$ & SVN \\
\hline Linyphiidae & Agyneta & simplicitarsis & 00786295 & SPSLO299-13 & KX039061 & $\mathrm{MNH}, \mathrm{SI}$ & SVN \\
\hline Linyphiidae & Bolyphantes & alticeps & 00786465 & SPSLO205-12 & & $\mathrm{MNH}, \mathrm{SI}$ & CHE \\
\hline Linyphiidae & Bolyphantes & luteolus & 00786397 & SPSLO101-12 & KX039101 & $\mathrm{MNH}, \mathrm{SI}$ & $\mathrm{CHE}$ \\
\hline Linyphiidae & Bolyphantes & luteolus & ARA0214 & SPSLO366-13 & KX039100 & NMBE & $\mathrm{CHE}$ \\
\hline Linyphiidae & Caracladus & avicula & 00786474 & SPSLO206-12 & KX039104 & $\mathrm{MNH}, \mathrm{SI}$ & $\mathrm{CHE}$ \\
\hline Linyphiidae & Caracladus & avicula & ARA0231 & SPSLO368-13 & KX039105 & NMBE & $\mathrm{CHE}$ \\
\hline Linyphiidae & Caracladus & zamoniensis & 00786441 & SPSLO102-12 & KX039106 & $\mathrm{MNH}, \mathrm{SI}$ & $\mathrm{CHE}$ \\
\hline Linyphiidae & Centromerus & pabulator & 00786451 & SPSLO207-12 & KX039108 & $\mathrm{MNH}, \mathrm{SI}$ & $\mathrm{CHE}$ \\
\hline Linyphiidae & Centromerus & pabulator & ARA0421 & SPSLO464-13 & KX039107 & NMBE & $\mathrm{CHE}$ \\
\hline Linyphiidae & Centromerus & subalpinus & 00786412 & SPSLO208-12 & KX039110 & $\mathrm{MNH}, \mathrm{SI}$ & $\mathrm{CHE}$ \\
\hline Linyphiidae & Centromerus & subalpinus & ARA0250 & SPSLO375-13 & KX039109 & NMBE & CHE \\
\hline Linyphiidae & Ceratinella & brevipes & 00786317 & SPSLO234-12 & KX039112 & $\mathrm{MNH}, \mathrm{SI}$ & $\mathrm{CHE}$ \\
\hline Linyphiidae & Ceratinella & brevipes & 00786450 & SPSLO103-12 & KX039113 & $\mathrm{MNH}, \mathrm{SI}$ & CHE \\
\hline Linyphiidae & Ceratinella & brevipes & ARA0363 & SPSLO413-13 & KX039111 & NMBE & $\mathrm{CHE}$ \\
\hline Linyphiidae & Diplocephalus & crassilobus & 00786294 & SPSLO296-13 & KX039144 & $\mathrm{MNH}, \mathrm{SI}$ & SVN \\
\hline Linyphiidae & Diplocephalus & latifrons & 00786461 & SPSLO209-12 & KX039145 & $\mathrm{MNH}, \mathrm{SI}$ & $\mathrm{CHE}$ \\
\hline Linyphiidae & Diplostyla & concolor & 00786533 & SPSLO049-12 & KX039146 & $\mathrm{MNH}, \mathrm{SI}$ & SVN \\
\hline Linyphiidae & Drapetisca & socialis & 00786587 & SPSLO050-12 & KX039149 & $\mathrm{MNH}, \mathrm{SI}$ & SVN \\
\hline Linyphiidae & Drapetisca & socialis & ARA0405 & SPSLO451-13 & KX039148 & EZ LAB & SVN \\
\hline
\end{tabular}




\begin{tabular}{|c|c|c|c|c|c|c|c|}
\hline Linyphiidae & Entelecara & acuminata & 00786460 & SPSLO210-12 & KX039164 & $\mathrm{MNH}, \mathrm{SI}$ & $\mathrm{CHE}$ \\
\hline Linyphiidae & Erigone & atra & ARA0257 & SPSLO377-13 & KX039171 & NMBE & $\mathrm{CHE}$ \\
\hline Linyphiidae & Erigone & dentipalpis & ARA0256 & SPSLO376-13 & KX039172 & NMBE & $\mathrm{CHE}$ \\
\hline Linyphiidae & Erigone & remota & 00786416 & SPSLO107-12 & KX039174 & $\mathrm{MNH}, \mathrm{SI}$ & $\mathrm{CHE}$ \\
\hline Linyphiidae & Erigonella & ignobilis & ARA0164 & SPSLO357-13 & KX039173 & NMBE & $\mathrm{CHE}$ \\
\hline Linyphiidae & Floronia & bucculenta & 00786545 & SPSL0051-12 & KX039183 & $\mathrm{MNH}, \mathrm{SI}$ & SVN \\
\hline Linyphiidae & Frontinellina & frutetorum & 00786567 & SPSLO052-12 & KX039184 & $\mathrm{MNH}, \mathrm{SI}$ & SVN \\
\hline Linyphiidae & Frontinellina & frutetorum & ARA0441 & SPSLO480-13 & KX039185 & EZ LAB & SVN \\
\hline Linyphiidae & Gonatium & hilare & 00786565 & SPSLO053-12 & KX039189 & $\mathrm{MNH}, \mathrm{SI}$ & SVN \\
\hline Linyphiidae & Gonatium & rubellum & 00786318 & SPSLO212-12 & KX039191 & $\mathrm{MNH}, \mathrm{SI}$ & $\mathrm{CHE}$ \\
\hline Linyphiidae & Gonatium & rubellum & ARA0386 & SPSLO434-13 & KX039190 & NMBE & $\mathrm{CHE}$ \\
\hline Linyphiidae & Gonatium & rubens & 00786331 & SPSLO213-12 & KX039192 & $\mathrm{MNH}, \mathrm{SI}$ & $\mathrm{CHE}$ \\
\hline Linyphiidae & Gonatium & rubens & ARA0358 & SPSLO408-13 & KX039193 & NMBE & $\mathrm{CHE}$ \\
\hline Linyphiidae & Improphantes & nitidus & 00786449 & SPSLO109-12 & KX039218 & $\mathrm{MNH}, \mathrm{SI}$ & $\mathrm{CHE}$ \\
\hline Linyphiidae & Incestophantes & frigidus & ARA0211 & SPSLO364-13 & & NMBE & $\mathrm{CHE}$ \\
\hline Linyphiidae & Kaestneria & dorsalis & 00786598 & SPSLO054-12 & KX039221 & $\mathrm{MNH}, \mathrm{SI}$ & SVN \\
\hline Linyphiidae & Lepthyphantes & leprosus & 00786342 & SPSLO214-12 & KX039225 & $\mathrm{MNH}, \mathrm{SI}$ & SVN \\
\hline Linyphiidae & Lepthyphantes & nodifer & ARA0433 & SPSLO473-13 & KX039226 & NMBE & $\mathrm{CHE}$ \\
\hline Linyphiidae & Linyphia & hortensis & 00786526 & SPSLO112-12 & KX039230 & $\mathrm{MNH}, \mathrm{SI}$ & SVN \\
\hline Linyphiidae & Linyphia & hortensis & ARA0397 & SPSLO443-13 & KX039231 & NMBE & $\mathrm{CHE}$ \\
\hline Linyphiidae & Linyphia & triangularis & 00786547 & SPSLO056-12 & KX039232 & $\mathrm{MNH}, \mathrm{SI}$ & SVN \\
\hline Linyphiidae & Linyphia & triangularis & ARA0004 & SPSLO327-13 & KX039233 & EZ LAB & SVN \\
\hline Linyphiidae & Macrargus & rufus & ARA0213 & SPSL0365-13 & KX039237 & NMBE & $\mathrm{CHE}$ \\
\hline Linyphiidae & Mansuphantes & fragilis & 00786415 & SPSLO114-12 & KX039243 & $\mathrm{MNH}, \mathrm{SI}$ & $\mathrm{CHE}$ \\
\hline Linyphiidae & Mansuphantes & fragilis & ARA0276 & SPSLO380-13 & KX039244 & NMBE & $\mathrm{CHE}$ \\
\hline Linyphiidae & Maso & sundevalli & 00786400 & SPSLO216-12 & KX039248 & $\mathrm{MNH}, \mathrm{SI}$ & $\mathrm{CHE}$ \\
\hline Linyphiidae & Maso & sundevalli & ARA0360 & SPSLO410-13 & KX039247 & NMBE & $\mathrm{CHE}$ \\
\hline Linyphiidae & Megalepthyphantes & collinus & 00786569 & SPSLO057-12 & KX039249 & $\mathrm{MNH}, \mathrm{SI}$ & SVN \\
\hline Linyphiidae & Mermessus & trilobatus & 00786395 & SPSLO118-12 & KX039250 & $\mathrm{MNH}, \mathrm{SI}$ & SVN \\
\hline Linyphiidae & Metopobactrus & prominulus & 00786437 & SPSLO119-12 & KX039257 & $\mathrm{MNH}, \mathrm{SI}$ & $\mathrm{CHE}$ \\
\hline Linyphiidae & Micrargus & alpinus & ARA0270 & SPSLO379-13 & KX039260 & NMBE & $\mathrm{CHE}$ \\
\hline
\end{tabular}




\begin{tabular}{|c|c|c|c|c|c|c|c|}
\hline Linyphiidae & Micrargus & herbigradus & 00786466 & SPSLO223-12 & KX039261 & $\mathrm{MNH}, \mathrm{SI}$ & $\mathrm{CHE}$ \\
\hline Linyphiidae & Microctenonyx & subitaneus & 00786463 & SPSLO224-12 & KX039262 & $\mathrm{MNH}, \mathrm{SI}$ & $\mathrm{CHE}$ \\
\hline Linyphiidae & Microlinyphia & impigra & 00786350 & SPSLO228-12 & KX039263 & $\mathrm{MNH}, \mathrm{SI}$ & $\mathrm{CHE}$ \\
\hline Linyphiidae & Microlinyphia & impigra & ARA0369 & SPSLO418-13 & KX039264 & NMBE & $\mathrm{CHE}$ \\
\hline Linyphiidae & Microlinyphia & pusilla & 00786417 & SPSLO225-12 & KX039265 & $\mathrm{MNH}, \mathrm{SI}$ & $\mathrm{CHE}$ \\
\hline Linyphiidae & Minicia & marginella & 00786371 & SPSLO120-12 & KX039267 & $\mathrm{MNH}, \mathrm{SI}$ & SVN \\
\hline Linyphiidae & Minicia & marginella & ARA0410 & SPSLO455-13 & KX039268 & NMBE & $\mathrm{CHE}$ \\
\hline Linyphiidae & Minyriolus & pusillus & ARA0285 & SPSLO382-13 & KX039269 & NMBE & $\mathrm{CHE}$ \\
\hline Linyphiidae & Mughiphantes & cornutus & ARA0372 & SPSLO421-13 & KX039272 & NMBE & $\mathrm{CHE}$ \\
\hline Linyphiidae & Mughiphantes & mughi & 00786319 & SPSLO227-12 & KX039274 & $\mathrm{MNH}, \mathrm{SI}$ & $\mathrm{CHE}$ \\
\hline Linyphiidae & Mughiphantes & mughi & 00786322 & SPSLO217-12 & KX039275 & $\mathrm{MNH}, \mathrm{SI}$ & $\mathrm{CHE}$ \\
\hline Linyphiidae & Mughiphantes & mughi & ARA0361 & SPSLO411-13 & KX039273 & NMBE & $\mathrm{CHE}$ \\
\hline Linyphiidae & Mughiphantes & mughi & ARA0411 & SPSLO456-13 & KX039276 & NMBE & $\mathrm{CHE}$ \\
\hline Linyphiidae & Nematogmus & sanguinolentus & 00786490 & SPSLO162-12 & KX039279 & $\mathrm{MNH}, \mathrm{SI}$ & SVN \\
\hline Linyphiidae & Nematogmus & sanguinolentus & ARA0359 & SPSLO409-13 & KX039278 & NMBE & $\mathrm{CHE}$ \\
\hline Linyphiidae & Neriene & clathrata & ARA0352 & SPSLO402-13 & KX039287 & EZ LAB & SVN \\
\hline Linyphiidae & Neriene & furtiva & 00786471 & SPSLO229-12 & KX039289 & $\mathrm{MNH}, \mathrm{SI}$ & SVN \\
\hline Linyphiidae & Neriene & furtiva & ARA0145 & SPSLO353-13 & KX039288 & EZ LAB & SVN \\
\hline Linyphiidae & Neriene & radiata & ARA0152 & SPSLO354-13 & KX039290 & NMBE & $\mathrm{CHE}$ \\
\hline Linyphiidae & Obscuriphantes & obscurus & 00786354 & SPSLO231-12 & KX039295 & $\mathrm{MNH}, \mathrm{SI}$ & $\mathrm{CHE}$ \\
\hline Linyphiidae & Obscuriphantes & obscurus & ARA0407 & SPSLO453-13 & KX039294 & NMBE & $\mathrm{CHE}$ \\
\hline Linyphiidae & Oedothorax & gibbifer & 00786396 & SPSLO232-12 & KX039296 & $\mathrm{MNH}, \mathrm{SI}$ & $\mathrm{CHE}$ \\
\hline Linyphiidae & Oryphantes & angulatus & ARA0398 & SPSLO444-13 & & NMBE & $\mathrm{CHE}$ \\
\hline Linyphiidae & Ostearius & melanopygius & 00786339 & SPSLO122-12 & KX039297 & $\mathrm{MNH}, \mathrm{SI}$ & SVN \\
\hline Linyphiidae & Palliduphantes & pallidus & 00786341 & SPSLO233-12 & KX039302 & $\mathrm{MNH}, \mathrm{SI}$ & $\mathrm{CHE}$ \\
\hline Linyphiidae & Panamomops & tauricornis & ARA0375 & SPSLO424-13 & KX039303 & NMBE & $\mathrm{CHE}$ \\
\hline Linyphiidae & Pityohyphantes & phrygianus & 00786316 & SPSLO236-12 & KX039351 & $\mathrm{MNH}, \mathrm{SI}$ & $\mathrm{CHE}$ \\
\hline Linyphiidae & Pityohyphantes & phrygianus & ARA0347 & SPSLO397-13 & KX039352 & NMBE & $\mathrm{CHE}$ \\
\hline Linyphiidae & Pocadicnemis & juncea & 00786421 & SPSLO237-12 & KX039354 & $\mathrm{MNH}, \mathrm{SI}$ & $\mathrm{CHE}$ \\
\hline Linyphiidae & Pocadicnemis & juncea & ARA0409 & SPSLO454-13 & KX039355 & NMBE & $\mathrm{CHE}$ \\
\hline Linyphiidae & Pocadicnemis & pumila & 00786422 & SPSLO238-12 & KX039356 & $\mathrm{MNH}, \mathrm{SI}$ & $\mathrm{CHE}$ \\
\hline
\end{tabular}




\begin{tabular}{|c|c|c|c|c|c|c|c|}
\hline Linyphiidae & Porrhomma & pallidum & 00786410 & SPSLO239-12 & KX039357 & $\mathrm{MNH}, \mathrm{SI}$ & $\mathrm{CHE}$ \\
\hline Linyphiidae & Porrhomma & pygmaeum & 00786292 & SPSLO301-13 & & $\mathrm{MNH}, \mathrm{SI}$ & SVN \\
\hline Linyphiidae & Scotinotylus & alpigena & 00786444 & SPSLO125-12 & KX039367 & $\mathrm{MNH}, \mathrm{SI}$ & $\mathrm{CHE}$ \\
\hline Linyphiidae & Scotinotylus & alpigena & ARA0163 & SPSLO356-13 & KX039366 & NMBE & $\mathrm{CHE}$ \\
\hline Linyphiidae & Scotinotylus & clavatus & 00786420 & SPSLO240-12 & KX039368 & $\mathrm{MNH}, \mathrm{SI}$ & $\mathrm{CHE}$ \\
\hline Linyphiidae & Silometopus & elegans & 00786409 & SPSLO126-12 & KX039373 & $\mathrm{MNH}, \mathrm{SI}$ & $\mathrm{CHE}$ \\
\hline Linyphiidae & Tapinocyba & affinis & 00786406 & SPSL0127-12 & KX039387 & $\mathrm{MNH}, \mathrm{SI}$ & $\mathrm{CHE}$ \\
\hline Linyphiidae & Tapinocyba & affinis & ARA0362 & SPSLO412-13 & KX039386 & NMBE & $\mathrm{CHE}$ \\
\hline Linyphiidae & Tenuiphantes & alacris & 00786343 & SPSLO241-12 & KX039389 & $\mathrm{MNH}, \mathrm{SI}$ & $\mathrm{CHE}$ \\
\hline Linyphiidae & Tenuiphantes & alacris & ARA0420 & SPSLO463-13 & KX039388 & NMBE & $\mathrm{CHE}$ \\
\hline Linyphiidae & Tenuiphantes & cristatus & 00786305 & SPSLO302-13 & KX039390 & $\mathrm{MNH}, \mathrm{SI}$ & $\mathrm{CHE}$ \\
\hline Linyphiidae & Tenuiphantes & cristatus & ARA0418 & SPSLO461-13 & KX039391 & NMBE & $\mathrm{CHE}$ \\
\hline Linyphiidae & Tenuiphantes & flavipes & 00786528 & SPSLO060-12 & KX039392 & $\mathrm{MNH}, \mathrm{SI}$ & SVN \\
\hline Linyphiidae & Tenuiphantes & flavipes & ARA0336 & SPSLO389-13 & KX039393 & NMBE & $\mathrm{CHE}$ \\
\hline Linyphiidae & Tenuiphantes & jacksoni & 00786356 & SPSLO242-12 & & $\mathrm{MNH}, \mathrm{SI}$ & $\mathrm{CHE}$ \\
\hline Linyphiidae & Tenuiphantes & jacksoni & 00786430 & SPSLO128-12 & & $\mathrm{MNH}, \mathrm{SI}$ & $\mathrm{CHE}$ \\
\hline Linyphiidae & Tenuiphantes & jacksoni & ARA0435 & SPSLO475-13 & & NMBE & $\mathrm{CHE}$ \\
\hline Linyphiidae & Tenuiphantes & jacksonoides & ARA0374 & SPSLO423-13 & KX039394 & NMBE & $\mathrm{CHE}$ \\
\hline Linyphiidae & Tenuiphantes & mengei & 00786301 & SPSLO300-13 & KX039396 & $\mathrm{MNH}, \mathrm{SI}$ & $\mathrm{CHE}$ \\
\hline Linyphiidae & Tenuiphantes & mengei & 00786413 & SPSLO243-12 & KX039397 & $\mathrm{MNH}, \mathrm{SI}$ & $\mathrm{CHE}$ \\
\hline Linyphiidae & Tenuiphantes & mengei & ARA0415 & SPSLO459-13 & KX039395 & NMBE & $\mathrm{CHE}$ \\
\hline Linyphiidae & Tenuiphantes & tenebricola & 00786418 & SPSLO244-12 & KX039398 & $\mathrm{MNH}, \mathrm{SI}$ & $\mathrm{CHE}$ \\
\hline Linyphiidae & Tenuiphantes & tenebricola & ARA0414 & SPSLO458-13 & KX039399 & NMBE & $\mathrm{CHE}$ \\
\hline Linyphiidae & Tenuiphantes & tenuis & 00786383 & SPSLO129-12 & & $\mathrm{MNH}, \mathrm{SI}$ & SVN \\
\hline Linyphiidae & Tiso & aestivus & ARA0422 & SPSLO465-13 & KX039413 & NMBE & $\mathrm{CHE}$ \\
\hline Linyphiidae & Tiso & vagans & 00786351 & SPSLO246-12 & KX039414 & $\mathrm{MNH}, \mathrm{SI}$ & $\mathrm{CHE}$ \\
\hline Linyphiidae & Tiso & vagans & ARA0401 & SPSLO447-13 & KX039415 & NMBE & $\mathrm{CHE}$ \\
\hline Linyphiidae & Walckenaeria & antica & 00786429 & SPSLO130-12 & KX039421 & $\mathrm{MNH}, \mathrm{SI}$ & $\mathrm{CHE}$ \\
\hline Linyphiidae & Walckenaeria & furcillata & 00786431 & SPSLO131-12 & KX039422 & $\mathrm{MNH}, \mathrm{SI}$ & $\mathrm{CHE}$ \\
\hline Liocranidae & Agroeca & brunnea & 00786320 & SPSLO247-12 & KX039046 & $\mathrm{MNH}, \mathrm{SI}$ & SVN \\
\hline Liocranidae & Agroeca & brunnea & ARA0392 & SPSLO439-13 & KX039047 & EZ LAB & SVN \\
\hline
\end{tabular}




\begin{tabular}{|c|c|c|c|c|c|c|c|}
\hline Liocranidae & Liocranum & rupicola & 00786516 & SPSL0061-12 & KX039234 & $\mathrm{MNH}, \mathrm{SI}$ & SVN \\
\hline Liphistiidae & Liphistius & $\mathrm{sp}$ & ARA0240 & SPSLO482-15 & KX039235 & EZ LAB & MYS \\
\hline Lycosidae & Alopecosa & accentuata & 00786365 & SPSLO248-12 & & $\mathrm{MNH}, \mathrm{SI}$ & CHE \\
\hline Lycosidae & Alopecosa & pulverulenta & 00786527 & SPSL0063-12 & KX039064 & $\mathrm{MNH}, \mathrm{SI}$ & SVN \\
\hline Lycosidae & Alopecosa & pulverulenta & ARA0349 & SPSLO399-13 & KX039063 & NMBE & $\mathrm{CHE}$ \\
\hline Lycosidae & Alopecosa & sulzeri & 00786452 & SPSLO249-12 & KX039065 & $\mathrm{MNH}, \mathrm{SI}$ & SVN \\
\hline Lycosidae & Alopecosa & taeniata & 00786538 & SPSLO062-12 & KX039066 & $\mathrm{MNH}, \mathrm{SI}$ & $\mathrm{CHE}$ \\
\hline Lycosidae & Alopecosa & trabalis & 00786509 & SPSLO064-12 & KX039067 & $\mathrm{MNH}, \mathrm{SI}$ & SVN \\
\hline Lycosidae & Alopecosa & trabalis & ARA0438 & SPSLO478-13 & KX039068 & EZ LAB & SVN \\
\hline Lycosidae & Arctosa & fulvolineata & 00786336 & SPSLO250-12 & & $\mathrm{MNH}, \mathrm{SI}$ & SVN \\
\hline Lycosidae & Arctosa & lutetiana & 00786407 & SPSLO132-12 & & $\mathrm{MNH}, \mathrm{SI}$ & SVN \\
\hline Lycosidae & Arctosa & maculata & 00786312 & SPSL0305-13 & KX039092 & $\mathrm{MNH}, \mathrm{SI}$ & SVN \\
\hline Lycosidae & Aulonia & albimana & 00786524 & SPSLO133-12 & KX039099 & $\mathrm{MNH}, \mathrm{SI}$ & SVN \\
\hline Lycosidae & Aulonia & albimana & ARA0338 & SPSLO391-13 & KX039098 & EZ LAB & SVN \\
\hline Lycosidae & Hogna & radiata & 00786502 & SPSLO065-12 & KX039210 & $\mathrm{MNH}, \mathrm{SI}$ & SVN \\
\hline Lycosidae & Hogna & radiata & ARA0368 & SPSLO417-13 & KX039209 & EZ LAB & SVN \\
\hline Lycosidae & Pardosa & agrestis & 00786385 & SPSLO134-12 & KX039309 & $\mathrm{MNH}, \mathrm{SI}$ & SVN \\
\hline Lycosidae & Pardosa & amentata & 00786337 & SPSLO251-12 & KX039311 & $\mathrm{MNH}, \mathrm{SI}$ & SVN \\
\hline Lycosidae & Pardosa & amentata & ARA0413 & SPSLO457-13 & KX039310 & NMBE & $\mathrm{CHE}$ \\
\hline Lycosidae & Pardosa & bifasciata & 00786453 & SPSLO252-12 & KX039312 & $\mathrm{MNH}, \mathrm{SI}$ & SVN \\
\hline Lycosidae & Pardosa & blanda & 00786358 & SPSLO253-12 & KX039314 & $\mathrm{MNH}, \mathrm{SI}$ & $\mathrm{CHE}$ \\
\hline Lycosidae & Pardosa & blanda & ARA0345 & SPSL0396-13 & KX039313 & NMBE & $\mathrm{CHE}$ \\
\hline Lycosidae & Pardosa & cf. lugubris & 00786529 & SPSL0066-12 & KX039316 & $\mathrm{MNH}, \mathrm{SI}$ & CHE \\
\hline Lycosidae & Pardosa & cf. lugubris & ARA0065 & SPSLO340-13 & KX039315 & EZ LAB & SVN \\
\hline Lycosidae & Pardosa & ferruginea & 00786309 & SPSLO306-13 & KX039317 & $\mathrm{MNH}, \mathrm{SI}$ & CHE \\
\hline Lycosidae & Pardosa & hortensis & 00786289 & SPSLO307-13 & KX039318 & $\mathrm{MNH}, \mathrm{SI}$ & SVN \\
\hline Lycosidae & Pardosa & oreophila & 00786310 & SPSLO308-13 & KX039319 & $\mathrm{MNH}, \mathrm{SI}$ & $\mathrm{CHE}$ \\
\hline Lycosidae & Pardosa & oreophila & 00786321 & SPSLO254-12 & KX039320 & $\mathrm{MNH}, \mathrm{SI}$ & CHE \\
\hline Lycosidae & Pardosa & oreophila & ARA0348 & SPSLO398-13 & KX039321 & NMBE & $\mathrm{CHE}$ \\
\hline Lycosidae & Pardosa & palustris & 00786514 & SPSLO067-12 & KX039323 & $\mathrm{MNH}, \mathrm{SI}$ & SVN \\
\hline Lycosidae & Pardosa & palustris & ARA0406 & SPSLO452-13 & KX039322 & NMBE & $\mathrm{CHE}$ \\
\hline
\end{tabular}




\begin{tabular}{|c|c|c|c|c|c|c|c|}
\hline Lycosidae & Pardosa & proxima & 00786311 & SPSLO309-13 & KX039324 & $\mathrm{MNH}, \mathrm{SI}$ & SVN \\
\hline Lycosidae & Pardosa & riparia & 00786315 & SPSLO310-13 & KX039326 & $\mathrm{MNH}, \mathrm{SI}$ & SVN \\
\hline Lycosidae & Pardosa & riparia & ARA0243 & SPSLO372-13 & KX039325 & NMBE & $\mathrm{CHE}$ \\
\hline Lycosidae & Pirata & piraticus & 00786375 & SPSLO255-12 & KX039346 & $\mathrm{MNH}, \mathrm{SI}$ & $\mathrm{CHE}$ \\
\hline Lycosidae & Pirata & piraticus & ARA0430 & SPSLO471-13 & KX039347 & NMBE & $\mathrm{CHE}$ \\
\hline Lycosidae & Piratula & hygrophila & 00786388 & SPSLO135-12 & KX039348 & $\mathrm{MNH}, \mathrm{SI}$ & SVN \\
\hline Lycosidae & Piratula & knorri & 00786402 & SPSLO136-12 & & $\mathrm{MNH}, \mathrm{SI}$ & SVN \\
\hline Lycosidae & Trochosa & spinipalpis & 00786344 & SPSLO137-12 & & $\mathrm{MNH}, \mathrm{SI}$ & SVN \\
\hline Lycosidae & Trochosa & spinipalpis & ARA0388 & SPSLO436-13 & & EZ LAB & SVN \\
\hline Lycosidae & Xerolycosa & nemoralis & 00786541 & SPSL0068-12 & KX039424 & $\mathrm{MNH}, \mathrm{SI}$ & $\mathrm{CHE}$ \\
\hline Lycosidae & Xerolycosa & nemoralis & ARA0335 & SPSL0388-13 & KX039423 & NMBE & $\mathrm{CHE}$ \\
\hline Mimetidae & Ero & furcata & 00786390 & SPSLO256-12 & KX039175 & $\mathrm{MNH}, \mathrm{SI}$ & $\mathrm{CHE}$ \\
\hline Miturgidae & Cheiracanthium & erraticum & 00786367 & SPSLO138-12 & KX039117 & $\mathrm{MNH}, \mathrm{SI}$ & SVN \\
\hline Miturgidae & Cheiracanthium & mildei & 00786355 & SPSLO139-12 & KX039118 & $\mathrm{MNH}, \mathrm{SI}$ & SVN \\
\hline Miturgidae & Cheiracanthium & punctorium & 00786519 & SPSLO140-12 & KX039120 & $\mathrm{MNH}, \mathrm{SI}$ & SVN \\
\hline Miturgidae & Cheiracanthium & punctorium & ARA0056 & SPSL0337-13 & KX039119 & EZ LAB & SVN \\
\hline Nemesiidae & Nemesia & pannonica & 00786333 & SPSL0311-13 & KX039280 & $\mathrm{MNH}, \mathrm{SI}$ & SVN \\
\hline Philodromidae & Philodromus & albidus & 00786272 & SPSLO312-13 & KX039332 & $\mathrm{MNH}, \mathrm{SI}$ & SVN \\
\hline Philodromidae & Philodromus & aureolus & 00786539 & SPSLO069-12 & KX039333 & $\mathrm{MNH}, \mathrm{SI}$ & SVN \\
\hline Philodromidae & Philodromus & cespitum & 00786513 & SPSLO070-12 & KX039335 & $\mathrm{MNH}, \mathrm{SI}$ & $\mathrm{CHE}$ \\
\hline Philodromidae & Philodromus & cespitum & ARA0400 & SPSLO446-13 & KX039334 & EZ LAB & SVN \\
\hline Philodromidae & Philodromus & dispar & 00786492 & SPSLO142-12 & KX039336 & $\mathrm{MNH}, \mathrm{SI}$ & SVN \\
\hline Philodromidae & Philodromus & praedatus & 00786500 & SPSLO071-12 & KX039338 & $\mathrm{MNH}, \mathrm{SI}$ & SVN \\
\hline Philodromidae & Philodromus & praedatus & ARA0404 & SPSLO450-13 & KX039337 & NMBE & $\mathrm{CHE}$ \\
\hline Philodromidae & Philodromus & pulchellus & 00786475 & SPSLO072-12 & KX039339 & $\mathrm{MNH}, \mathrm{SI}$ & SVN \\
\hline Philodromidae & Philodromus & pulchellus & ARA0344 & SPSLO395-13 & KX039340 & EZ LAB & SVN \\
\hline Philodromidae & Philodromus & vagulus & 00786366 & SPSLO257-12 & & $\mathrm{MNH}, \mathrm{SI}$ & $\mathrm{CHE}$ \\
\hline Philodromidae & Philodromus & vagulus & ARA0351 & SPSLO401-13 & & NMBE & $\mathrm{CHE}$ \\
\hline Philodromidae & Thanatus & formicinus & 00786530 & SPSLO073-12 & KX039403 & $\mathrm{MNH}, \mathrm{SI}$ & SVN \\
\hline Philodromidae & Tibellus & macellus & 00786493 & SPSLO074-12 & KX039412 & $\mathrm{MNH}, \mathrm{SI}$ & SVN \\
\hline Philodromidae & Tibellus & macellus & ARA0334 & SPSLO387-13 & KX039411 & EZ LAB & SVN \\
\hline
\end{tabular}




\begin{tabular}{|c|c|c|c|c|c|c|c|}
\hline Pholcidae & Psilochorus & simoni & 00786501 & SPSLO076-12 & KX039359 & $\mathrm{MNH}, \mathrm{SI}$ & SVN \\
\hline Pisauridae & Pisaura & mirabilis & 00786487 & SPSLO144-12 & KX039349 & $\mathrm{MNH}, \mathrm{SI}$ & SVN \\
\hline Pisauridae & Pisaura & mirabilis & ARA0383 & SPSLO431-13 & KX039350 & NMBE & CHE \\
\hline Salticidae & Evarcha & arcuata & 00786332 & SPSLO259-12 & KX039177 & $\mathrm{MNH}, \mathrm{SI}$ & $\mathrm{CHE}$ \\
\hline Salticidae & Evarcha & arcuata & ARA0062 & SPSLO338-13 & KX039178 & EZ LAB & SVN \\
\hline Salticidae & Evarcha & falcata & 00786408 & SPSLO145-12 & & $\mathrm{MNH}, \mathrm{SI}$ & SVN \\
\hline Salticidae & Evarcha & falcata & ARA0037 & SPSLO331-13 & KX039179 & EZ LAB & SVN \\
\hline Salticidae & Evarcha & jucunda & 00786503 & SPSLO077-12 & KX039180 & $\mathrm{MNH}, \mathrm{SI}$ & SVN \\
\hline Salticidae & Evarcha & michailovi & 00786313 & SPSLO313-13 & & $\mathrm{MNH}, \mathrm{SI}$ & SVN \\
\hline Salticidae & Evarcha & michailovi & 00786458 & SPSLO260-12 & & $\mathrm{MNH}, \mathrm{SI}$ & SVN \\
\hline Salticidae & Evarcha & michailovi & ARA0436 & SPSLO476-13 & & EZ LAB & SVN \\
\hline Salticidae & Hasarius & adansoni & 00786348 & SPSLO261-12 & KX039197 & $\mathrm{MNH}, \mathrm{SI}$ & SVN \\
\hline Salticidae & Heliophanus & aeneus & 00786293 & SPSLO314-13 & & $\mathrm{MNH}, \mathrm{SI}$ & SVN \\
\hline Salticidae & Heliophanus & auratus & 00786282 & SPSLO315-13 & KX039198 & $\mathrm{MNH}, \mathrm{SI}$ & SVN \\
\hline Salticidae & Heliophanus & cupreus & 00786518 & SPSLO146-12 & KX039199 & $\mathrm{MNH}, \mathrm{SI}$ & SVN \\
\hline Salticidae & Heliophanus & cupreus & ARA0382 & SPSLO430-13 & KX039200 & NMBE & $\mathrm{CHE}$ \\
\hline Salticidae & Heliophanus & flavipes & 00786510 & SPSLO147-12 & KX039202 & $\mathrm{MNH}, \mathrm{SI}$ & SVN \\
\hline Salticidae & Heliophanus & flavipes & ARA0396 & SPSLO442-13 & KX039201 & EZ LAB & SVN \\
\hline Salticidae & Heliophanus & kochii & 00786495 & SPSLO078-12 & KX039203 & $\mathrm{MNH}, \mathrm{SI}$ & SVN \\
\hline Salticidae & Icius & subinermis & 00786381 & SPSLO148-12 & KX039217 & $\mathrm{MNH}, \mathrm{SI}$ & SVN \\
\hline Salticidae & Leptorchestes & berolinensis & 00786512 & SPSLO079-12 & KX039227 & $\mathrm{MNH}, \mathrm{SI}$ & SVN \\
\hline Salticidae & Macaroeris & nidicolens & 00786338 & SPSLO262-12 & KX039236 & $\mathrm{MNH}, \mathrm{SI}$ & SVN \\
\hline Salticidae & Marpissa & muscosa & 00786523 & SPSLO080-12 & KX039245 & $\mathrm{MNH}, \mathrm{SI}$ & SVN \\
\hline Salticidae & Marpissa & nivoyi & 00786496 & SPSLO081-12 & KX039246 & $\mathrm{MNH}, \mathrm{SI}$ & SVN \\
\hline Salticidae & Myrmarachne & formicaria & 00786432 & SPSLO149-12 & KX039277 & $\mathrm{MNH}, \mathrm{SI}$ & SVN \\
\hline Salticidae & Neon & reticulatus & 00786370 & SPSLO150-12 & KX039281 & $\mathrm{MNH}, \mathrm{SI}$ & SVN \\
\hline Salticidae & Pellenes & seriatus & 00786462 & SPSLO263-12 & KX039329 & $\mathrm{MNH}, \mathrm{SI}$ & SVN \\
\hline Salticidae & Pellenes & seriatus & 00786504 & SPSLO082-12 & KX039327 & $\mathrm{MNH}, \mathrm{SI}$ & SVN \\
\hline Salticidae & Pellenes & seriatus & ARA0439 & SPSLO479-13 & KX039328 & EZ LAB & SVN \\
\hline Salticidae & Philaeus & chrysops & 00786472 & SPSLO264-12 & KX039331 & $\mathrm{MNH}, \mathrm{SI}$ & SVN \\
\hline Salticidae & Pseudeuophrys & lanigera & 00786280 & SPSLO316-13 & KX039358 & MNH, SI & SVN \\
\hline
\end{tabular}




\begin{tabular}{|c|c|c|c|c|c|c|c|}
\hline Salticidae & Saitis & barbipes & 00786507 & SPSLO083-12 & KX039363 & $\mathrm{MNH}, \mathrm{SI}$ & SVN \\
\hline Salticidae & Salticus & scenicus & 00786362 & SPSLO265-12 & KX039364 & $\mathrm{MNH}, \mathrm{SI}$ & $\mathrm{CHE}$ \\
\hline Salticidae & Sibianor & aurocinctus & 00786377 & SPSLO266-12 & & $\mathrm{MNH}, \mathrm{SI}$ & $\mathrm{CHE}$ \\
\hline Salticidae & Sibianor & aurocinctus & ARA0385 & SPSLO433-13 & & NMBE & $\mathrm{CHE}$ \\
\hline Salticidae & Sitticus & rupicola & 00786525 & SPSLO084-12 & KX039377 & $\mathrm{MNH}, \mathrm{SI}$ & $\mathrm{CHE}$ \\
\hline Salticidae & Sitticus & rupicola & ARA0378 & SPSLO426-13 & KX039378 & NMBE & $\mathrm{CHE}$ \\
\hline Scytodidae & Scytodes & thoracica & 00786521 & SPSLO085-12 & KX039371 & $\mathrm{MNH}, \mathrm{SI}$ & SVN \\
\hline Segestriidae & Segestria & senoculata & 00786281 & SPSLO317-13 & KX039372 & $\mathrm{MNH}, \mathrm{SI}$ & SVN \\
\hline Sparassidae & Micrommata & virescens & 00786497 & SPSLO086-12 & & $\mathrm{MNH}, \mathrm{SI}$ & SVN \\
\hline Sparassidae & Micrommata & virescens & ARA0365 & SPSLO414-13 & KX039266 & NMBE & $\mathrm{CHE}$ \\
\hline Tetragnathidae & Metellina & mengei & 00786536 & SPSL0087-12 & KX039251 & $\mathrm{MNH}, \mathrm{SI}$ & $\mathrm{CHE}$ \\
\hline Tetragnathidae & Metellina & mengei & ARA0373 & SPSLO422-13 & KX039252 & NMBE & $\mathrm{CHE}$ \\
\hline Tetragnathidae & Metellina & merianae & 00786298 & SPSLO318-13 & KX039253 & $\mathrm{MNH}, \mathrm{SI}$ & $\mathrm{CHE}$ \\
\hline Tetragnathidae & Metellina & merianae & ARA0394 & SPSLO441-13 & KX039254 & EZ LAB & SVN \\
\hline Tetragnathidae & Metellina & segmentata & 00786357 & SPSLO152-12 & KX039255 & $\mathrm{MNH}, \mathrm{SI}$ & SVN \\
\hline Tetragnathidae & Metellina & segmentata & ARA0431 & SPSLO472-13 & KX039256 & EZ LAB & SVN \\
\hline Tetragnathidae & Pachygnatha & degeeri & 00786399 & SPSLO153-12 & KX039300 & $\mathrm{MNH}, \mathrm{SI}$ & SVN \\
\hline Tetragnathidae & Tetragnatha & nigrita & 00786534 & SPSLO088-12 & KX039400 & $\mathrm{MNH}, \mathrm{SI}$ & SVN \\
\hline Tetragnathidae & Tetragnatha & nigrita & ARA0041 & SPSLO332-13 & KX039401 & EZ LAB & SVN \\
\hline Tetragnathidae & Tetragnatha & pinicola & 00786361 & SPSLO267-12 & KX039402 & $\mathrm{MNH}, \mathrm{SI}$ & $\mathrm{CHE}$ \\
\hline Tetragnathidae & Tetragnatha & pinicola & 00786520 & SPSLO155-12 & & $\mathrm{MNH}, \mathrm{SI}$ & SVN \\
\hline Theridiidae & Asagena & phalerata & 00786346 & SPSLO156-12 & KX039095 & $\mathrm{MNH}, \mathrm{SI}$ & SVN \\
\hline Theridiidae & Crustulina & guttata & 00786454 & SPSLO268-12 & KX039132 & $\mathrm{MNH}, \mathrm{SI}$ & SVN \\
\hline Theridiidae & Crustulina & guttata & ARA0437 & SPSLO477-13 & KX039131 & EZ LAB & SVN \\
\hline Theridiidae & Crustulina & scabripes & 00786479 & SPSLO089-12 & KX039134 & $\mathrm{MNH}, \mathrm{SI}$ & SVN \\
\hline Theridiidae & Crustulina & scabripes & ARA0137 & SPSLO352-13 & KX039133 & EZ LAB & SVN \\
\hline Theridiidae & Dipoena & melanogaster & 00786506 & SPSLO090-12 & KX039147 & $\mathrm{MNH}, \mathrm{SI}$ & SVN \\
\hline Theridiidae & Enoplognatha & afrodite & 00786532 & SPSLO157-12 & KX039160 & $\mathrm{MNH}, \mathrm{SI}$ & SVN \\
\hline Theridiidae & Enoplognatha & afrodite & ARA0135 & SPSLO350-13 & KX039159 & EZ LAB & SVN \\
\hline Theridiidae & Enoplognatha & latimana & 00786329 & SPSLO269-12 & KX039161 & $\mathrm{MNH}, \mathrm{SI}$ & $\mathrm{CHE}$ \\
\hline Theridiidae & Enoplognatha & ovata & 00786515 & SPSL0158-12 & KX039163 & MNH, SI & SVN \\
\hline
\end{tabular}




\begin{tabular}{|c|c|c|c|c|c|c|c|}
\hline Theridiidae & Enoplognatha & ovata & ARA0367 & SPSLO416-13 & KX039162 & NMBE & $\mathrm{CHE}$ \\
\hline Theridiidae & Episinus & angulatus & 00786386 & SPSLO159-12 & KX039165 & $\mathrm{MNH}, \mathrm{SI}$ & SVN \\
\hline Theridiidae & Episinus & maculipes & 00786488 & SPSLO160-12 & KX039166 & $\mathrm{MNH}, \mathrm{SI}$ & SVN \\
\hline Theridiidae & Episinus & truncatus & 00786327 & SPSLO270-12 & KX039168 & $\mathrm{MNH}, \mathrm{SI}$ & $\mathrm{CHE}$ \\
\hline Theridiidae & Episinus & truncatus & ARA0132 & SPSLO349-13 & KX039167 & EZ LAB & SVN \\
\hline Theridiidae & Euryopis & flavomaculata & 00786468 & SPSLO271-12 & KX039176 & $\mathrm{MNH}, \mathrm{SI}$ & SVN \\
\hline Theridiidae & Heterotheridion & nigrovariegatum & 00786482 & SPSLO161-12 & KX039206 & $\mathrm{MNH}, \mathrm{SI}$ & SVN \\
\hline Theridiidae & Heterotheridion & nigrovariegatum & ARA0343 & SPSLO394-13 & KX039205 & EZ LAB & SVN \\
\hline Theridiidae & Neottiura & bimaculata & 00786445 & SPSLO163-12 & KX039284 & $\mathrm{MNH}, \mathrm{SI}$ & SVN \\
\hline Theridiidae & Neottiura & bimaculata & ARA0366 & SPSLO415-13 & KX039283 & NMBE & $\mathrm{CHE}$ \\
\hline Theridiidae & Neottiura & herbigrada & 00786467 & SPSLO272-12 & KX039285 & $\mathrm{MNH}, \mathrm{SI}$ & SVN \\
\hline Theridiidae & Neottiura & suaveolens & 00786427 & SPSLO164-12 & KX039286 & $\mathrm{MNH}, \mathrm{SI}$ & SVN \\
\hline Theridiidae & Paidiscura & pallens & 00786288 & SPSLO319-13 & KX039301 & $\mathrm{MNH}, \mathrm{SI}$ & SVN \\
\hline Theridiidae & Parasteatoda & lunata & 00786476 & SPSLO165-12 & KX039304 & $\mathrm{MNH}, \mathrm{SI}$ & SVN \\
\hline Theridiidae & Parasteatoda & tepidariorum & 00786531 & SPSL0091-12 & KX039305 & $\mathrm{MNH}, \mathrm{SI}$ & SVN \\
\hline Theridiidae & Parasteatoda & tepidariorum & ARA0329 & SPSLO384-13 & KX039306 & EZ LAB & SVN \\
\hline Theridiidae & Phylloneta & impressa & 00786401 & SPSLO273-12 & KX039342 & $\mathrm{MNH}, \mathrm{SI}$ & $\mathrm{CHE}$ \\
\hline Theridiidae & Phylloneta & impressa & ARA0428 & SPSLO469-13 & KX039343 & NMBE & $\mathrm{CHE}$ \\
\hline Theridiidae & Phylloneta & sisyphia & 00786364 & SPSLO274-12 & KX039344 & $\mathrm{MNH}, \mathrm{SI}$ & $\mathrm{CHE}$ \\
\hline Theridiidae & Phylloneta & sisyphia & ARA0416 & SPSLO460-13 & KX039345 & NMBE & $\mathrm{CHE}$ \\
\hline Theridiidae & Platnickina & tincta & 00786380 & SPSL0167-12 & KX039353 & $\mathrm{MNH}, \mathrm{SI}$ & SVN \\
\hline Theridiidae & Robertus & lividus & ARA0201 & SPSL0363-13 & KX039360 & NMBE & $\mathrm{CHE}$ \\
\hline Theridiidae & Robertus & mediterraneus & 00786334 & SPSLO275-12 & & $\mathrm{MNH}, \mathrm{SI}$ & $\mathrm{CHE}$ \\
\hline Theridiidae & Robertus & mediterraneus & 00786433 & SPSLO168-12 & & $\mathrm{MNH}, \mathrm{SI}$ & $\mathrm{CHE}$ \\
\hline Theridiidae & Robertus & scoticus & 00786290 & SPSLO320-13 & & $\mathrm{MNH}, \mathrm{SI}$ & SVN \\
\hline Theridiidae & Robertus & truncorum & 00786435 & SPSLO169-12 & KX039361 & $\mathrm{MNH}, \mathrm{SI}$ & $\mathrm{CHE}$ \\
\hline Theridiidae & Robertus & truncorum & ARA0280 & SPSL0381-13 & KX039362 & NMBE & $\mathrm{CHE}$ \\
\hline Theridiidae & Sardinidion & blackwalli & 00786271 & SPSLO321-13 & KX039365 & $\mathrm{MNH}, \mathrm{SI}$ & SVN \\
\hline Theridiidae & Simitidion & simile & 00786549 & SPSLO170-12 & KX039375 & $\mathrm{MNH}, \mathrm{SI}$ & SVN \\
\hline Theridiidae & Simitidion & simile & ARA0442 & SPSLO481-13 & KX039374 & EZ LAB & SVN \\
\hline Theridiidae & Steatoda & bipunctata & 00786325 & SPSLO276-12 & KX039380 & $\mathrm{MNH}, \mathrm{SI}$ & $\mathrm{CHE}$ \\
\hline
\end{tabular}




\begin{tabular}{|c|c|c|c|c|c|c|c|}
\hline Theridiidae & Steatoda & bipunctata & ARA0029 & SPSLO328-13 & KX039379 & EZ LAB & SVN \\
\hline Theridiidae & Steatoda & triangulosa & 00786489 & SPSLO171-12 & KX039382 & $\mathrm{MNH}, \mathrm{SI}$ & SVN \\
\hline Theridiidae & Steatoda & triangulosa & ARA0046 & SPSLO334-13 & KX039381 & EZ LAB & SVN \\
\hline Theridiidae & Theridion & betteni & 00786340 & SPSLO277-12 & KX039404 & $\mathrm{MNH}, \mathrm{SI}$ & CHE \\
\hline Theridiidae & Theridion & pinastri & 00786480 & SPSLO172-12 & KX039406 & $\mathrm{MNH}, \mathrm{SI}$ & SVN \\
\hline Theridiidae & Theridion & pinastri & ARA0136 & SPSLO351-13 & KX039405 & EZ LAB & SVN \\
\hline Theridiidae & Theridion & varians & 00786374 & SPSLO173-12 & KX039408 & $\mathrm{MNH}, \mathrm{SI}$ & SVN \\
\hline Theridiidae & Theridion & varians & ARA0043 & SPSLO333-13 & KX039407 & EZ LAB & SVN \\
\hline Thomisidae & Diaea & livens & 00786359 & SPSLO174-12 & KX039138 & $\mathrm{MNH}, \mathrm{SI}$ & SVN \\
\hline Thomisidae & Ebrechtella & tricuspidata & 00786508 & SPSLO092-12 & KX039157 & $\mathrm{MNH}, \mathrm{SI}$ & SVN \\
\hline Thomisidae & Ebrechtella & tricuspidata & ARA0033 & SPSLO330-13 & KX039158 & EZ LAB & SVN \\
\hline Thomisidae & Heriaeus & hirtus & 00786469 & SPSLO278-12 & KX039204 & $\mathrm{MNH}, \mathrm{SI}$ & SVN \\
\hline Thomisidae & Misumena & vatia & 00786387 & SPSLO175-12 & KX039270 & $\mathrm{MNH}, \mathrm{SI}$ & SVN \\
\hline Thomisidae & Misumena & vatia & ARA0081 & SPSLO342-13 & KX039271 & EZ LAB & SVN \\
\hline Thomisidae & Ozyptila & atomaria & 00786522 & SPSLO176-12 & KX039298 & $\mathrm{MNH}, \mathrm{SI}$ & $\mathrm{CHE}$ \\
\hline Thomisidae & Ozyptila & nigrita & 00786499 & SPSLO093-12 & KX039299 & $\mathrm{MNH}, \mathrm{SI}$ & SVN \\
\hline Thomisidae & Synema & globosum & 00786485 & SPSLO177-12 & KX039384 & $\mathrm{MNH}, \mathrm{SI}$ & SVN \\
\hline Thomisidae & Synema & globosum & ARA0390 & SPSLO438-13 & KX039385 & NMBE & $\mathrm{CHE}$ \\
\hline Thomisidae & Thomisus & onustus & 00786455 & SPSLO280-12 & KX039410 & $\mathrm{MNH}, \mathrm{SI}$ & SVN \\
\hline Thomisidae & Thomisus & onustus & ARA0426 & SPSLO467-13 & KX039409 & EZ LAB & SVN \\
\hline Thomisidae & Tmarus & piger & 00786484 & SPSLO178-12 & KX039417 & $\mathrm{MNH}, \mathrm{SI}$ & SVN \\
\hline Thomisidae & Tmarus & piger & ARA0376 & SPSLO425-13 & KX039418 & EZ LAB & SVN \\
\hline Thomisidae & Xysticus & acerbus & 00786483 & SPSLO179-12 & KX039425 & $\mathrm{MNH}, \mathrm{SI}$ & SVN \\
\hline Thomisidae & Xysticus & audax & 00786347 & SPSLO180-12 & KX039427 & $\mathrm{MNH}, \mathrm{SI}$ & SVN \\
\hline Thomisidae & Xysticus & audax & ARA0402 & SPSLO448-13 & KX039426 & EZ LAB & SVN \\
\hline Thomisidae & Xysticus & bifasciatus & 00786543 & SPSLO181-12 & KX039428 & $\mathrm{MNH}, \mathrm{SI}$ & SVN \\
\hline Thomisidae & Xysticus & cristatus & 00786537 & SPSLO182-12 & KX039430 & $\mathrm{MNH}, \mathrm{SI}$ & SVN \\
\hline Thomisidae & Xysticus & cristatus & ARA0389 & SPSLO437-13 & KX039429 & NMBE & CHE \\
\hline Thomisidae & Xysticus & desidiosus & 00786372 & SPSLO183-12 & & $\mathrm{MNH}, \mathrm{SI}$ & SVN \\
\hline Thomisidae & Xysticus & erraticus & 00786275 & SPSLO322-13 & KX039431 & $\mathrm{MNH}, \mathrm{SI}$ & SVN \\
\hline Thomisidae & Xysticus & kempeleni & 00786486 & SPSL0184-12 & KX039432 & $\mathrm{MNH}, \mathrm{SI}$ & SVN \\
\hline
\end{tabular}




$\begin{array}{ll}\text { Thomisidae } & \text { Xysticus } \\ \text { Thomisidae } & \text { Xysticus } \\ \text { Thomisidae } & \text { Xysticus } \\ \text { Thomisidae } & \text { Xysticus } \\ \text { Thomisidae } & \text { Xysticus } \\ \text { Thomisidae } & \text { Xysticus } \\ \text { Thomisidae } & \text { Xysticus } \\ \text { Thomisidae } & \text { Xysticus } \\ \text { Titanoecidae } & \text { Titanoeca } \\ \text { Uloboridae } & \text { Hyptiotes } \\ \text { Uloboridae } & \text { Hyptiotes } \\ \text { Uloboridae } & \text { Uloborus } \\ \text { Zoridae } & \text { Zora } \\ \text { Zoridae } & \text { Zora }\end{array}$

kochi
kochi
lanio
lineatus
lineatus
macedonicus
tenebrosus
tenebrosus
tristis
paradoxus
paradoxus
walckenaerius
spinimana
spinimana

$\begin{array}{lllll}00786303 & \text { SPSLO323-13 } & \text { KX039433 } & \text { MNH, SI } & \text { SVN } \\ \text { ARA0434 } & \text { SPSLO474-13 } & \text { KX039434 } & \text { EZ LAB } & \text { SVN } \\ 00786477 & \text { SPSLO185-12 } & \text { KX039435 } & \text { MNH, SI } & \text { SVN } \\ 00786535 & \text { SPSLO186-12 } & \text { KX039437 } & \text { MNH, SI } & \text { SVN } \\ \text { ARA0304 } & \text { SPSLO383-13 } & \text { KX039436 } & \text { EZ LAB } & \text { SVN } \\ 00786376 & \text { SPSLO281-12 } & \text { KX039438 } & \text { MNH, SI } & \text { CHE } \\ 00786478 & \text { SPSLO187-12 } & \text { KX039440 } & \text { MNH, SI } & \text { SVN } \\ \text { ARA0332 } & \text { SPSLO385-13 } & \text { KX039439 } & \text { EZ LAB } & \text { SVN } \\ 00786297 & \text { SPSLO324-13 } & \text { KX039416 } & \text { MNH, SI } & \text { SVN } \\ 00786546 & \text { SPSLO188-12 } & \text { KX039216 } & \text { MNH, SI } & \text { SVN } \\ \text { ARA0241 } & \text { SPSLO370-13 } & \text { KX039215 } & \text { EZ LAB } & \text { SVN } \\ 00786324 & \text { SPSLO282-12 } & \text { KX039420 } & \text { MNH, SI } & \text { SVN } \\ 00786494 & \text { SPSLO094-12 } & \text { KX039449 } & \text { MNH, SI } & \text { SVN } \\ \text { ARA0192 } & \text { SPSLO361-13 } & \text { KX039448 } & \text { NMBE } & \text { CHE }\end{array}$


3

Importance of library representation.

Figure 3. Relation between proportion of best sequence identity and numbers of species per genus, and genera per family (thresholds 95 and 91 respectively). 

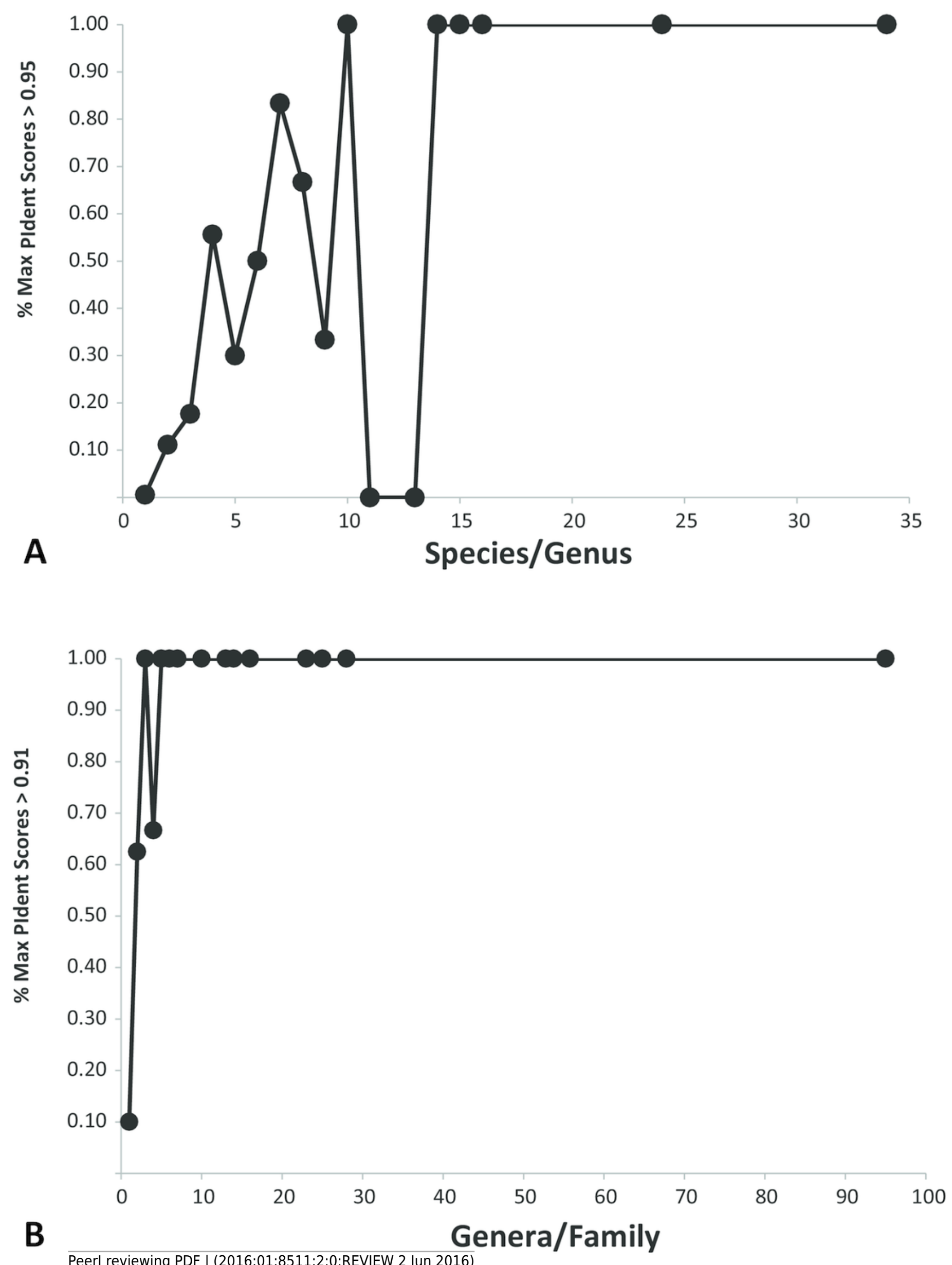